This is a revised personal version of the text of the final journal article, which is made available for scholarly purposes only, in accordance with the journal's author permissions. The full citation is:

A. Serna-Maza, S. Heaven, C.J. Banks. (2015) Biogas stripping of ammonia from fresh digestate from a food waste digester. Bioresource Technology (in press) DOI: 10.1016/j.biortech.2015.04.041

\title{
Biogas stripping of ammonia from fresh digestate from a food waste digester
} Author names and affiliations

A. Serna-Maza ${ }^{1}$, S. Heaven, C.J. Banks

Faculty of Engineering and the Environment, University of Southampton, SO17 1BJ, UK

\begin{abstract}
The efficiency of ammonia removal from fresh source-segregated domestic food waste digestate using biogas as a stripping agent was studied in batch experiments at 35, 55 and $70{ }^{\circ} \mathrm{C}$, at gas flow rates of 0.125 and $0.250 \mathrm{~L}_{\text {biogas }} \mathrm{min}^{-1} \mathrm{~L}^{-1}$ digestate with and without $\mathrm{pH}$ adjustment. Higher temperatures and alkaline conditions were required for effective ammonia removal, and at $35{ }^{\circ} \mathrm{C}$ with or without $\mathrm{pH}$ adjustment or $55^{\circ} \mathrm{C}$ with unadjusted $\mathrm{pH}$ there was little or no removal. Results were compared to those from earlier studies with digestate that had been stored prior to stripping and showed that ammonia removal from fresh digestate was more difficult, with time constants 1.6 to 5.7 times higher than those previously reported. This has implications for the design of large-scale systems where continuous stripping of fresh digestate is likely to be the normal operating mode. A mass balance approach showed that thermal-alkaline stripping improved hydrolysis.
\end{abstract}

Keywords: Ammonia removal; hydrolysis; biogas stripping; anaerobic digestion; food waste

${ }^{1}$ Corresponding author: Tel: +33 02380598363, email A.Serna-Maza@soton.ac.uk 
Introduction

Source segregated domestic food waste (SS-DFW) represents a large biomass waste stream: stabilisation of this by anaerobic digestion (AD) can help towards meeting environmental protection targets such as the EU Directive on the landfilling of waste (1999/31/EC). Further added value benefits are the recovery of a fuel gas and the provision of a mechanism by which nutrients can be recycled back to land through digestate application. Although anaerobic digestion can offer numerous benefits (EC, 2010), the digestion of SS-DFW can also present operational difficulties, primarily due to its high protein content. Hydrolysis of this material releases free and ionised ammonia: the latter is essential for the growth of anaerobic microorganisms, but both forms can be inhibitory to the anaerobic consortium, including methanogenic Archaea, and especially to the acetoclastic methanogens (Angelidaki and Ahring, 1993; Kayhanian, 1999; Liu and Sung, 2002; Schnürer and Nordberg, 2008). Partial inhibition of methanogenesis can cause operational instability due to volatile fatty acid (VFA) accumulation, leading to a decrease in biogas production, and in the worst cases to failure of the digestion process (Angelidaki and Ahring, 1993; Poggi-Varaldo et al., 1997; Hansen et al., 1998).

Banks et al. (2012) showed that, given appropriate trace element supplementation to stimulate acetate oxidation and hydrogenotrophic methanogenesis, mesophilic AD of SS-DFW could be achieved without reducing the total ammonia nitrogen (TAN) concentration by water addition. More recent work (VALORGAS, 2013) has shown that with this trace element supplementation, operation at TAN concentrations above $6 \mathrm{~g} \mathrm{~N} \mathrm{~L}^{-1}$ and an organic loading rate (OLR) up to $8 \mathrm{~g} \mathrm{VS} \mathrm{L}^{-1}$ day $^{-1}$ is possible with no loss in digestion performance. An increase in temperature to the thermophilic range, however, leads to an increase in the ratio of free ammonia nitrogen (FAN) to TAN from $11 \%$ to $28 \%$, which in turns reduces the threshold of ammonia toxicity, and thus thermophilic digestion of SS-DFW is unstable. This was clearly demonstrated in a comparative study by Yirong et al. (2013a) which showed the onset of failure in thermophilic SS-DFW digesters when TAN concentrations reached $3.0 \mathrm{~g} \mathrm{~N}$ $\mathrm{L}^{-1}$. A parallel study with acclimatisation to thermophilic conditions using a low nitrogen (1.45 \% of dry weight) synthetic food waste showed long-term stable operation was possible in thermophilic conditions, while subsequent increases in the nitrogen concentration by addition of urea to this feedstock confirmed that the critical TAN concentration was between 2.5-3.0 $\mathrm{g} \mathrm{N} \mathrm{L}^{-1}$ (Yirong et al., 2013b; VALORGAS, 2013), equivalent to FAN concentrations of $590-710 \mathrm{mg} \mathrm{N} \mathrm{L}^{-1}$ at the operational $\mathrm{pH}$. This threshold value is similar to that reported in other studies where suppression of methanogenic activity as a result of ammonia toxicity has been demonstrated in thermophilic systems (Angelidaki and Ahring, 1993; Borja et al., 1996; Hansen et al., 1998; Angelidaki et al., 2006; Nielsen and Ahring, 2007).

To maximise the specific methane yield in thermophilic digestion of SS-DFW while avoiding VFA accumulation and process instability, one approach is to reduce the TAN concentration in the digester by gas stripping. Ammonia stripping has been trialled using a range of approaches, including with and without solid/liquid separation and using air, nitrogen, steam or biogas as the stripping agent (Bonmati and Flotats, 2003; Ledda et al., 2013; Jiang et al., 2013; Nie et al., 2015; Zeng et al., 2006; Walker et al., 2011). Stripping with biogas has several advantages: the cost is low since biogas is 
produced on site in the anaerobic digestion process, and the risk of stripping carbonate from the digestate is reduced. Ammonia stripping on the feedstock prior to digestion can only be successfully applied to materials such as manures where a high percentage of the total Kjeldahl nitrogen (TKN) is present as TAN. In the case of SS-DFW this is not feasible, as only about 7\% of TKN in kerbside collected food waste is available as TAN, and further pre-hydrolysis leads to rapid acidification and lowering of $\mathrm{pH}$ (Defra, 2010). An alternative is to allow hydrolysis to proceed in the digester itself, as is normal, and then remove ammonia in a side-stream stripping configuration. This approach has some merit, as previous studies have reported an increase in stripping efficiency at higher alkalinities and ammonia concentrations (Campos et al., 2013); digestion also lowers the organic matter content, which reduces cation binding and increases the proportion of ammonia that is strippable. Laureni et al. (2013) found that digestate storage decreased the total solids, chemical oxygen demand, VFA concentration and alkalinity and improved the ammonia stripping efficiency. Other factors may also affect the binding capacity of digestate for ammonia; but the above findings clearly indicate that the ammonia stripping process is strongly dependent on digestate characteristics. These results therefore throw some doubt on the kinetic values and time constants reported in the studies by De la Rubia et al. (2010) and Walker et al. (2011), which used digestate that had been stored over long periods. The methodology employed in these studies was effective, however, and showed the value of using biogas as the stripping medium at flow rates between 0.125 to $0.750 \mathrm{~L}_{\text {biogas }} \mathrm{min}^{-1} \mathrm{~L}^{-1}$ digestate, and at different temperatures $\left(35,55\right.$ and $70{ }^{\circ} \mathrm{C}$ ), with and without $\mathrm{pH}$ adjustment using $\mathrm{NaOH}$. A similar approach was thus adopted in the current study, but with the important difference that fresh digestate samples were taken directly from an operational food waste digester for each experimental run. The main objective of the current work was thus to gather data on the ammonia stripping performance parameters of fresh SS-DFW digestate under a number of different stripping conditions, to provide data for the design of side-stream systems coupled to anaerobic digesters as a means of reducing TAN concentrations to non-inhibitory values for thermophilic digestion.

\section{$2 \quad$ Materials and methods}

\section{$2.1 \quad$ Food waste digestion}

Two 75-L working volume continuously-stirred tank reactors (CSTR) as previously described by Zhang et al. (2012) were operated as food waste digesters at a temperature of $36 \pm 1{ }^{\circ} \mathrm{C}$ (Figure 1a). They were inoculated with digestate from a commercial AD plant treating SS-DFW (Biocycle digester, operated by BiogenGreenfinch, Ludlow, UK). The digesters were then fed daily on SS-DFW collected commercially by Veolia Environmental Services (UK) from households in Eastleigh, Hampshire, UK. A representative sample of around $300 \mathrm{~kg}$ was taken periodically as required, from material collected in the same collection round. The food waste was taken out of the biodegradable bags in which it is collected, and any obvious non-food contamination was removed along with large bones and seeds. The sample was then ground (S52/010 Waste Disposer, IMC Limited, UK) to a homogeneous pulp, well mixed as a single batch and frozen at $-18{ }^{\circ} \mathrm{C}$ in $\sim 4 \mathrm{~kg}$ aliquots in snap-top plastic containers. When needed, the feedstock was thawed then stored at $4{ }^{\circ} \mathrm{C}$ and used within a short period. The characteristics of the inoculum and of the different batches of food waste used in the experiment are shown in Table 1. 
The digesters were operated for 462 days (4 hydraulic retention time) at an OLR of $2 \mathrm{~g} \mathrm{VS} \mathrm{kg}^{-1}$ day $^{-1}$ to provide fresh digestate samples from a stable and well-operated digestion process with a known history, running under conditions typical of full-scale $\mathrm{AD}$ plant. The digesters were supplemented with trace elements according to the recommendations of Banks et al. (2012) and were monitored for pH, TAN, alkalinity, VFA, biogas production and gas composition. Biogas production was measured continuously using tipping-bucket gas flow meters (Walker et al., 2009). At least once per fortnight the biogas was collected in a gas-impermeable bag for 0.5-hour periods starting 5 hours after reactor feeding. This sample was used to determine the biogas composition.

\subsection{Batch operated ammonia stripping column}

The experimental procedure for batch ammonia stripping was based on Walker et al. (2011). The stripping column was a $56 \mathrm{~cm}$ high glass tube with a $10 \mathrm{~cm}$ internal diameter which tapered to an inlet fitted with a sintered glass diffusor disc of $3 \mathrm{~cm}$ diameter. The column was enclosed in a water jacket with inlet and outlet hose connections: column temperature was maintained by the circulation of hot water through the jacket using a thermo-circulator (Techne Circulator C-85A). The stripping gas used was a mixture of $65 \% \mathrm{CH}_{4}$ and $35 \% \mathrm{CO}_{2}$ (v/v) (BOC, UK). The gas was maintained in a gas-impermeable storage bag and a proportion of it was used to flush the system, in order to replace the air initially present in the column. Stripping gas could then be drawn from the top of the stripping column by means of a peristaltic pump (Watson Marlow Sci-Q 323), and circulated back to the bottom of the column in a gas circulation loop containing ammonia traps. These were simply a set of conical flasks connected in series: the first was a condensate trap, the second contained deionised water, the third a $0.25 \mathrm{~N} \mathrm{H}_{2} \mathrm{SO}_{4}$ acid trap, and finally a second deionised water trap. This series of traps gave complete removal of ammonia from the gas stream, allowing it to operate as a closed loop. The gas bag was also incorporated into the loop and acted as a gas reservoir mitigating any subsequent volume changes in the system. The experimental set-up is shown in Figure 1b.

In operation the column was filled with $2 \mathrm{~kg}$ of the digestate under test, which was collected fresh from the wastage line of the 75-L digesters and sieved through a 1 mm mesh. The system was flushed by pumping the gas mixture at a rate of $0.380 \mathrm{~L} \mathrm{~min}^{-}$ ${ }^{1}$ for 15 minutes and venting the gas from the top of the stripping column. The gas loop was then closed to the ambient air and the peristaltic pump was set at the desired gas flow rate.

TAN concentrations in each of the traps were determined at the end of each experiment. The results of the first 5 experimental trials indicated that only two traps were needed (water and acid) and the number of traps was thus reduced to two in subsequent tests.

\subsection{Experimental runs using the ammonia stripping column}

Stripping experiments were carried out to assess the effect of $\mathrm{pH}$, temperature and gas flow rate, in all cases following the procedure described above. Stripping column temperatures of 35,55 and $70{ }^{\circ} \mathrm{C}$ were tested, at gas flow rates between 0.125 $0.250 \mathrm{~L} \mathrm{~min}^{-1}$, and with $\mathrm{pH}$ unadjusted or adjusted to 10 using $\mathrm{CaO}, \mathrm{Ca}(\mathrm{OH})_{2}$ or $\mathrm{NaOH}$. 
The effectiveness of the stripping process in terms of TAN removal rates and final percentage removal was compared to results from previous research (De la Rubia et al., 2010; Walker et al., 2011).

Further experiments were carried out to assess whether thermal-alkaline treatment promoted the degradation of organic nitrogen-containing materials into the ammonia form. The batch ammonia stripping equipment was used in this case at $70{ }^{\circ} \mathrm{C}$ without continuous stripping and at $\mathrm{pH} 10$ adjusted using $\mathrm{CaO}$. While the digestate was being heated two consecutive acid traps of $25 \mathrm{~mL}$ and $50 \mathrm{~mL}$ were used to capture any ammonia released as a result of the initial temperature increase. During the remainder of the experiment digestate TAN, TKN, pH and VFA concentration were monitored.

\subsection{Analytical methods}

Total solids (TS), volatile solids (VS), $\mathrm{pH}$, alkalinity, TKN, TAN and VFA concentrations and biogas composition $\left(\mathrm{CH}_{4}\right.$ and $\left.\mathrm{CO}_{2}\right)$ were determined following the analysis protocols described in Serna-Maza et al. (2014).

\subsection{Calculation methods}

\subsubsection{Ammonia removal rate}

In order to evaluate the effectiveness of the stripping technique and to allow comparison with the results of previous studies, the concept of the time constant was used (Walker et al., 2011). The experimental TAN concentration profile obtained for each stripping condition was fitted to an exponential decay curve ( $1^{\text {st }}$ order kinetic) as shown in equation 1.

$\mathrm{C}=\mathrm{C}_{\mathrm{o}} \cdot \mathrm{e}^{\frac{-\mathrm{t}}{\tau}}$

where $\mathrm{C}$ is TAN concentration (mg $\mathrm{N} \mathrm{kg}^{-1}$ wet weight basis); $\mathrm{C}_{0}$ is the initial TAN concentration (mg N kg${ }^{-1}$ ww), $\mathrm{t}$ is time (hours) and $\tau$ is the ammonia removal time constant (hours). The time constant $\tau$ thus represents the time required to reduce the TAN concentration by $\left(1-\mathrm{e}^{-1}\right)$, or approximately $63 \%$ of the initial value, and allows quantitative comparison between experimental runs with different initial and final conditions.

\subsubsection{Nitrogen mass balance in batch striping columns}

A nitrogen balance for the batch stripping tower was carried out based on equations 2 and 3.

$\mathbf{N}_{\text {dig start }}=\mathbf{N}_{\text {dig end }}+\mathbf{N}_{\text {traps }}+\mathbf{N}_{\text {samples }}$

where $\mathrm{N}_{\text {dig start }}$ is the mass of nitrogen in the digestate at the start of the batch experiment (g); $\mathrm{N}_{\text {dig end }}$ is the mass of nitrogen in the digestate at the end of the batch experiment (g); $\mathrm{N}_{\text {traps }}$ is the mass of nitrogen in the ammonia traps (g) and $\mathrm{N}_{\text {samples }}$ is the mass of nitrogen sampled from the experiment as digestate (g). 
Mass $_{\text {dig in }} \cdot$ TKN $_{\text {dig in }}=$ Mass $_{\text {dig out }} \cdot$ TKN $_{\text {dig out }}+$ Mass $_{\text {cond }} \cdot$ TAN $_{\text {cond }}+$ Mass $_{\text {water }}$
TAN $_{\text {water }}+$ Mass $_{\text {acid }} \cdot$ TAN $_{\text {acid }}+\mathbf{N}_{\text {samples }}$

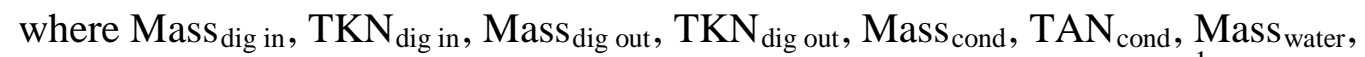
TAN $_{\text {water }}$, Mass ${ }_{\text {acid }}$ and TAN ${ }_{\text {acid }}$ refer to mass (kg) and TKN (mg N kg ${ }^{-1}{ }_{\text {ww }}$ ) of digestate at the start of the experiment, digestate at the end of the experiment, condensate, water and acid traps at the end of the experiment, respectively; and $\mathrm{N}_{\text {samples }}$ is the mass of nitrogen sampled from the experiment as digestate (g). The $\mathrm{N}_{\text {samples }}$ component was not included in calculation of $\mathrm{N}$ mass balances.

The unrecovered matter mass from the column was determined from equation 4.

Unrecovered $_{\text {matter }}=$ Mass $_{\text {dig in }}-$ Mass $_{\text {dig out }}-$ Mass $_{\text {sample }}-$ Mass gain $_{\text {traps }}-$ Solid $_{\text {recovered }}$

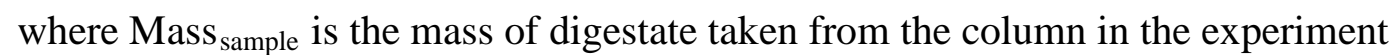
( $\sim 0.007 \mathrm{~kg}$ per sample); Mass gain traps $_{\text {is }}$ ine mass increase measured at the end of the experiment in the condensate, water and acid ammonia traps (kg); and Solid ${ }_{\text {recovered }}$ is the mass of solid in stripping column at the end of the experiment $(\mathrm{kg})$.

\subsubsection{Ammonia stripping efficiency}

The efficiency with which the stripping gas is used was calculated based on the difference between the ammonia concentration in the biogas after stripping and the theoretical concentration at equilibrium, according to equation 5.

$E=\left(1-\frac{H_{\text {equilibrium }}-H_{\text {stripping }}}{H_{\text {equilibrium }}}\right) \cdot 100$

where $\mathrm{E}$ is the efficiency or effectiveness of the biogas in the stripping column (\%); $\mathrm{H}_{\text {equilibrium }}$ is the proportionality constant $\left(\mathrm{kPa} \mathrm{kg} \mathrm{mol}^{-1} \mathrm{~N}\right)$ relating the solubility of ammonia in water to its partial pressure in the gas phase (in diluted gases) and is obtained from Henry's law (equation 6) (Perry and Green, 1999); $\mathrm{H}_{\text {stripping }}$ is the experimental proportionality constant $\left(\mathrm{kPa} \mathrm{kg} \mathrm{mol}^{-1} \mathrm{~N}\right)$ calculated according to the concept of Henry's law from the batch ammonia stripping results (equation 7).

$H_{\text {equilibrium }}=\frac{P_{N H 3}}{C_{F A N}}$

$H_{\text {stripping }}=\frac{P_{N H 3}^{\prime}}{C^{\prime}{ }_{F A N}}$

where $C_{\text {FAN }}$ is the concentration of the solute (FAN) in the liquid phase (mol N kg-1 ${ }_{\text {ww }}$ ); $\mathrm{C}_{\text {FAN }}^{\prime}$ is the experimental concentration of the solute (FAN) in the liquid phase (mol N $\left.\mathrm{kg}^{-1}{ }_{\mathrm{ww}}\right)$; $\mathrm{P}_{\mathrm{NH} 3}$ is the partial pressure $(\mathrm{kPa})$ of the solute (ammonia) in the gas phase in equilibrium with a certain $\mathrm{C}_{\mathrm{FAN}}$; $\mathrm{P}_{\mathrm{NH} 3}^{\prime}$ is experimental partial pressure of ammonia in the biogas phase during the stripping experiments $(\mathrm{kPa})$ and is defined according to equation 8 (Perry and Green, 1999).

$P^{\prime}{ }_{N H_{3}}=P_{T} \cdot Y_{N H_{3}}=P_{T} \cdot \frac{\operatorname{mol}_{N H_{3}}}{\operatorname{mol}_{T}}=\frac{(-1) \cdot 101.325}{14000 \cdot \operatorname{mol}_{T}} \frac{\Delta\left(\text { Mass }_{\text {column } \cdot C^{\prime}}{ }_{T A N}\right)}{\Delta t}$ 
where $\mathrm{P}_{\mathrm{T}}$ is the total pressure or the sum of the partial pressures of all the gas components $(\mathrm{kPa})$; $\mathrm{Y}_{\mathrm{NH} 3}$ is the mole fraction of ammonia in the gas; $\dot{\mathrm{mol}}_{\mathrm{NH}_{3}}$ and $\dot{\mathrm{mol}}_{\mathrm{T}}$ are the ammonia (mol N hour ${ }^{-1}$ ) and total gas mol flow (mol hour ${ }^{-1}$ ), respectively; Mass $_{\text {column }}$ is the mass of digestate in the stripping column (kg); $\mathrm{C}^{\prime}$ TAN is the digestate TAN concentration in the stripping column (mg N kg${ }^{-1}{ }_{w w}$ ); $\mathrm{t}$ is time (hours) and $\frac{\Delta\left(\text { Mass }_{\text {column }} \cdot C^{\prime} T_{A N}\right)}{\Delta t}$ indicates the rate of total ammonia nitrogen change in the stripping column (mg hour $\left.{ }^{-1}\right)$.

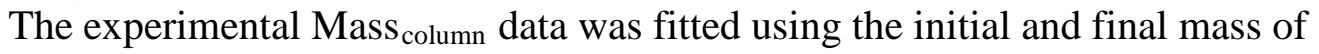
digestate in the stripping column to the following linear equation (equation 9).

Mass $_{\text {column }}=-C \cdot t+D$

where $\mathrm{C}$ and $\mathrm{D}$ are experimentally-obtained coefficients.

The TAN concentration was considered to decrease exponentially (equation 10).

$C_{T A N}^{\prime}=A \cdot e^{-B \cdot t}$

where A and B are experimentally-obtained coefficients.

$\mathrm{P}^{\prime}{ }_{\mathrm{NH} 3}$ in the stripping column is calculated from equation 11.

$P^{\prime}{ }_{N H_{3}}=K_{1} \cdot \frac{\Delta}{\Delta t}\left(A \cdot e^{-B \cdot t} \cdot(-C \cdot t+D)\right)=K_{1} \cdot\left(-B \cdot A \cdot e^{-B \cdot t} \cdot(-C \cdot t+D)-C \cdot A \cdot e^{-B \cdot t}\right)$

where $K_{1}=$ constant $=\frac{(-1) \cdot 101.325}{14000 \cdot \mathrm{mol}_{T}}$

Experimental values for digestate FAN concentration $\left(\mathrm{C}^{\prime}{ }_{\mathrm{FAN}}\right)$ in the stripping column (mol N kg${ }_{\text {ww }}$ ) are needed to allow determination of $\mathrm{H}_{\text {stripping. The experimental }}$ FAN decreases exponentially with time (equation 12).

$C_{F A N}^{\prime}=\frac{A^{\prime} \cdot e^{-B^{\prime} \cdot t}}{14000}$

where $\mathrm{A}^{\prime}$ and $\mathrm{B}^{\prime}$ are experimentally-obtained coefficients for $\mathrm{C}_{\mathrm{FAN}}$.

\section{$3 \quad$ Results and discussion}

\subsection{5-L food waste digesters}

The inoculum and feedstock characteristics are shown in Table 1a and b. Average values for performance and monitoring parameters during the steady state period are shown in Table 1c. The digesters performed well throughout the operating period. Specific biogas production was stable with values of $0.83 \pm 0.04 \mathrm{~L} \mathrm{~g}^{-1} \mathrm{VS}_{\text {added }}$ for digester 1 and $0.85 \pm 0.04 \mathrm{~L} \mathrm{~g}^{-1} \mathrm{VS}_{\text {added }}$ for digester 2, and average methane concentration was in the range 52.3 - $57.9 \%$. The VS destruction under steady state conditions was $84 \%$.

\subsection{Comparison of alkaline compounds for $\mathrm{pH}$ control}

To select a means of adjusting and maintaining $\mathrm{pH}$, an initial experiment was carried out comparing $\mathrm{CaO}$ (lime) and $\mathrm{Ca}(\mathrm{OH})_{2}$ (slaked lime). Each was added to $100 \mathrm{~g}$ of fresh food waste digestate and the $\mathrm{pH}$ was monitored over time without any stripping. 
An initial temperature increase was observed for $\mathrm{CaO}$ addition at the applied dosage of $20 \mathrm{~g} \mathrm{~kg}^{-1}$. This was not considered significant since the temperature remained below the lowest stripping temperature $\left(35^{\circ} \mathrm{C}\right)$; and therefore no temperature control was applied during $\mathrm{pH}$ adjustment. Both compounds were able to achieve the required final $\mathrm{pH}$ after 23 hours and to maintain it over time. Since $\mathrm{CaO}$ is easier to handle, and since the same dose of both compounds was needed to reach a certain $\mathrm{pH}, \mathrm{CaO}$ was selected in preference to $\mathrm{Ca}(\mathrm{OH})_{2}$. Lime is considered less inhibitory to AD than sodium or potassium hydroxide, but also less efficient as an alkaline agent (Zhang and Jahng, 2010; Kleybocker et al., 2012). The initial test carried out with $\mathrm{CaO}$ and $\mathrm{Ca}(\mathrm{OH})_{2}$ was therefore repeated for $\mathrm{NaOH}$, using a fresh sample of digestate from the same digester under the same operating conditions. $33.8 \mathrm{ml}$ of a $10 \mathrm{M} \mathrm{NaOH}$ solution (equivalent to $13.6 \mathrm{~g} \mathrm{NaOH}$ ) was needed per $\mathrm{kg}$ of sieved food waste digestate to increase the $\mathrm{pH}$ to 10 , compared to $20 \mathrm{~g}$ of $\mathrm{CaO}$.

Based on the results of the initial tests, batch stripping tests were carried out with $\mathrm{CaO}\left(20 \mathrm{~g} \mathrm{~kg}^{-1}\right)$ and $\mathrm{NaOH}\left(13.6 \mathrm{~g} \mathrm{~kg}^{-1}\right)$. The results are shown in Figure 2 and in the overall summary in Table 2 . At $70{ }^{\circ} \mathrm{C}$ the stripping performance with $\mathrm{NaOH}$ was slightly better, especially between $40-100$ hours, but at $35{ }^{\circ} \mathrm{C}$ there was little difference between the two alkaline agents. Since the performance of these two compounds is similar the final choice between them is likely to be based on operational and other factors. When $\mathrm{CaO}$ was used, long mixing times were needed to favour the hydration reaction in which calcium hydroxide is generated. The $\mathrm{CO}_{2}$ present in the biogas also reacts with $\mathrm{Ca}(\mathrm{OH})_{2}$ to form insoluble carbonate salts that could introduce operational problems such as solids blockage in the stripping column. Both $\mathrm{CaO}$ and $\mathrm{Ca}(\mathrm{OH})_{2}$, however, are widely used to increase $\mathrm{pH}$ before stripping treatments because of their low cost and the potential for phosphorus removal (Cheung, 1995). On the other hand, $\mathrm{NaOH}$ addition was an easy and quick method to increase $\mathrm{pH}$, but foaming problems occurred during the stripping process making it necessary to add antifoaming agent. There are also concerns that $\mathrm{AD}$ inhibition by the $\mathrm{Na}^{+}$cation could occur, as was observed within a short period during air stripping of pig manure (Zhang and Jahng, 2010; Zhang et al., 2011). Since this study aimed to provide data for the design of sidestream stripping systems, in which a proportion of the treated digestate is returned to the digester, the issue of $\mathrm{Na}^{+}$accumulation is a major consideration, and for this reason the use of $\mathrm{CaO}$ is preferred even though the dosage needed is 1.5 times higher than with $\mathrm{NaOH}$.

\subsection{Batch ammonia stripping experiments}

Figure S1 in supplementary data shows the digestate $\mathrm{pH}$ profiles during the batch stripping runs. When alkali was not added to the stripping column there was an initial increase in $\mathrm{pH}$ of $0.3-0.5$ units, probably caused by equilibration of carbonates and $\mathrm{CO}_{2}$ volatilisation. Increasing the temperature also decreases $\mathrm{CO}_{2}$ solubility, and this may have been associated with an initial generation of foam that decreased with time. As stripping progressed, in most cases the $\mathrm{pH}$ gradually decreased to $0.2-0.6$ units below the original value, but this was dependent on temperature: for example, at $35{ }^{\circ} \mathrm{C}$ without $\mathrm{pH}$ adjustment the $\mathrm{pH}$ remained constant during the 383-hour experimental run. 
When alkali was added to increase the $\mathrm{pH}$ at the start of the experiment, the final $\mathrm{pH}$ values decreased by $0.6-1.7$ units in all experimental runs. This is likely to be due to the removal of FAN, with consequent changes in the ammonia-ammonium equilibrium producing more dissolved gas and releasing some protons. The decrease in $\mathrm{pH}$ was only slight, however, since the carbonate system is the major buffering element.

TAN removal profiles from all the batch stripping runs are shown in Figure 2. It can be seen that without alkali addition no ammonia reduction occurred in mesophilic temperatures (run 1); even in thermophilic conditions (run 2 and 3) the average reduction was only $1.7 \% \mathrm{~N}$ per day. In these experiments the biogas flow rate was not regarded as being a limiting factor, as the flow rates used were greater than the $0.032 \mathrm{~m}^{3}$ $\mathrm{m}^{-2}$ tank cross-section min $^{-1}$ that corresponds to violent gas mixing in a reactor (Perry and Green, 1999). The free ammonia fraction of the digestate TAN at unadjusted $\mathrm{pH}(\mathrm{pH} 7)$ is $1 \%$ at $35{ }^{\circ} \mathrm{C}$ and $3 \%$ at $55^{\circ} \mathrm{C}$. This small difference in ammonia concentration between the stripping gas and free ammonia in the digestate means the driving force is low and thus the ammonia removal rate is poor. It was therefore concluded that a simple in situ stripping system operating in a digester at either 35 or $55{ }^{0} \mathrm{C}$ without $\mathrm{pH}$ adjustment would not be effective in reducing digestate ammonia concentrations. This result indicates that method proposed by Walker et al. (2011), of in situ stripping in a digester using a modified gas mixing system, would not be successful.

The TAN concentration profile for the stripping experiment at $55{ }^{\circ} \mathrm{C}$ (run 4) showed an initial increase in ammonia with the maximum concentration found after 35 43 hours of operation. This indicates that further hydrolysis was occurring leading to generation of ammonia nitrogen from $\mathrm{N}_{\text {org }}$, and the rate of production was greater than that of TAN removal by stripping. It is therefore possible that thermophilic treatment at $55{ }^{0} \mathrm{C}$ could give a slight improvement in the overall biogas yield from food waste, as there is some increase in degradation. Tampio et al. (2014) showed, however, that temperatures of $160{ }^{\circ} \mathrm{C}$ led to a reduction in biogas yields probably due to denaturation of proteins. The temperature limits where positive benefits may occur are not known.

Further evidence of degradation taking place in the stripping column can be seen in supplementary data Figure S2. In general, total VFA concentrations increased progressively with time during the stripping process. For this to occur it is likely that some particulate organic matter is being hydrolysed into soluble organics and then fermented. Increases in VFA caused by thermal hydrolysis of fresh OFMSW at high temperatures $\left(65-70{ }^{\circ} \mathrm{C}\right)$ and during digestion under thermophilic conditions have been previously reported (Rintala and Ahring, 1994; Hartmann and Ahring, 2005). In the current work no clear pattern was found and VFA production is likely to be influenced by many factors, e.g. duration of the stripping experiment, temperature, and initial $\mathrm{pH}$.

With the exception of run 1 at $35{ }^{\circ} \mathrm{C}$ where no TAN removal occurred, there was a clear decrease in alkalinity over the stripping period when alkali was not added at the start (data not shown). This is accounted for by carbonate destruction, which is promoted by FAN removal, increase in VFA concentration and precipitation of salts.

The above observations and results all indicate that further hydrolysis and acidification of the digestate could occur when it was taken from the main digester and 
vigorously sparged with biogas in a separate reactor. To measure the associated changes in TAN accurately a mass balance approach was adopted.

\subsection{Nitrogen mass balance in batch stripping columns}

In the stripping process part of the $\mathrm{N}_{\text {org }}$ in the digestate is broken down: the proportion varied between stripping conditions, with the lowest breakdown (7.3 - $9.4 \%)$ found at $35{ }^{\circ} \mathrm{C}$, unadjusted and modified $\mathrm{pH}$ (runs 1, 10 and 11), while the highest (34.9\%) was found at $55{ }^{\circ} \mathrm{C}$, non-modified $\mathrm{pH}$ (run 2). Tables S1 and S2 in supplementary data show the digestate characteristics at the start and end of the batch stripping runs.

Nitrogen mass balances (equations 2 and 3) were calculated for each of the 17 experimental runs (Table 2) and the results are shown in Figure 3. In most of these the TKN concentration in the digestate at the start of the experiment was higher than the sum of the TKN in the digestate at the end of the run and the nitrogen found in the traps. The main source of error in this balance is due to unrecovered material, including unaccounted-for $\mathrm{N}$ in the mass of digestate which remains attached to the column (Table S2, supplementary data) and in samples removed for analysis.

On average the unrecovered digestate was estimated at $59 \mathrm{~g}$. If this lost mass is added to the final mass of digestate the $\% \mathrm{~N}$ loss is reduced by $0.3-6.0 \%$. The amount of missing nitrogen could be further reduced if the volume sampled from the columns is added. Some of the lost mass could also be associated with crystallisation of nitrogen compounds inside the tubes in the stripping rig: this would further decrease the unaccounted-for nitrogen. A secondary source of error is the nitrogen loss during the air-flushing period. This loss is considered to be small, however, as the maximum mass of nitrogen present in the gas in the first 15 min of stripping was only 48 and $40 \mathrm{mg} \mathrm{N}$ (run 14 and 16 respectively).

Bonmati and Flotats (2003) reported similar problems with unrecovered nitrogen (6 to $16 \%$ ) during air stripping of ammonia from pig slurry. Laureni et al. (2013) attributed $\mathrm{N}$ losses (3 to $55 \%$ ) and overestimations (5 to $15 \%$ ) to manure and digestate attached to the filling material in the stripping column. These studies, however, carried out a TAN balance rather than a TKN balance: the latter is more accurate as it takes into account the breakdown of $\mathrm{N}_{\text {org }}$.

\subsection{Comparison of time constants}

\subsubsection{Previous studies}

Time constants found in the current research (Table 2) were from 1.6 to 5.7 times higher than those determined under the same experimental conditions in a previous study conducted by Walker et al. (2011). In that study two sources of food waste digestate, were used (digestate 1 : $\mathrm{TS}=5.50 \%$; TAN $=8000 \mathrm{mg} \mathrm{N} \mathrm{L}^{-1}$; $\mathrm{pH}$ 8.59.3; digestate 2 : $\mathrm{TS}=3.14 \%$; $\mathrm{TAN}=6000 \mathrm{mg} \mathrm{N} \mathrm{L}^{-1}$; $\mathrm{pH}=8.1-8.2$ ) and both were stored for periods of weeks or months prior to use; whereas the current work used fresh food waste digestate (TS = $6.60 \%$; TAN $=4560$ - $4925 \mathrm{mg} \mathrm{N} \mathrm{kg}^{-1}{ }_{\text {ww }}$; $\mathrm{pH}$ 7.9-8.3) obtained from a stable well-run pair of digesters. As the methodology used was identical, and both sets of digestate were from digestion of similar source segregated food wastes, the only major difference was that Walker's two digestates had been stored 
and the current set was fresh. It therefore appears that it is more difficult to strip ammonia from fresh food waste digestate than from stored digestates. These results support the findings of Laureni et al. (2013) that storage may affect stripping performance, but as the digestates tested differ slightly in a number of characteristics, e.g. TAN and solids content, VFA concentrations and alkalinity it is not yet clear which of these factors are most important in promoting higher ammonia removal. It is believed, however, that the time constants derived in the current study (Table 2) are representative of those for fresh digestate in well-operated digesters and are likely to be applicable to the design of full-scale ammonia stripping plant.

\subsubsection{Analysis of the effects of temperature, $\mathrm{pH}$ and biogas flow}

The effect on the time constant of changing the gas flow rate, stripping temperature and $\mathrm{pH}$ was analysed (Table 3). The results showed that in this flow range doubling of the gas flow rate does not induce a similar increase in ammonia removal. When the temperature or the $\mathrm{pH}$ in the stripping column is decreased, however, the time constant increases sharply. The purpose of increasing the digestate $\mathrm{pH}$ in the stripping process is to shift the ammonium-ammonia equilibrium to the gaseous ammonia form, increase the ammonia concentration gradient between the biogas and the digestate and favour the release of ammonia from the liquid phase. For example at $55^{\circ} \mathrm{C}$ an increase in $\mathrm{pH}$ from 7 to 10 increases the free ammonia as a fraction of TAN from $3 \%$ to $97 \%$. This is the main reason for the improved ammonia removal at higher $\mathrm{pH}$.

\subsection{Ammonia stripping efficiency}

Using the concept of Henry's law a relationship can be obtained between the FAN concentration in the liquid phase and the ammonia concentration expressed as partial pressure in the gas phase at each point in the experiment (equations 11 and 12). The $E$ value (equation 5 ) for each experiment shows the efficiency of the experimental conditions based on $\mathrm{H}_{\text {stripping }}$ and $\mathrm{H}_{\text {equilibrium }}$.

For all of the experimental runs, when $\mathrm{P}_{\mathrm{NH} 3}{ }_{\mathrm{N}}$ was plotted against $\mathrm{C}_{\mathrm{FAN}}$ to allow determination of $\mathrm{H}_{\text {stripping }}$ (equation 7), a linear relationship passing through the origin was found (Table 4).

The ammonia concentration of the biogas generated by the 75-L digesters in section 3.1 was analysed. The proportionality constant $\left(\mathrm{H}_{\text {digester }}\right)$ that relates the solubility of ammonia in water to its partial pressure in the gas was calculated following the principle of Henry's law. The results showed good agreement with the stripping experiments performed at natural $\mathrm{pH}$ and $35{ }^{\circ} \mathrm{C}$ (Figure S3a, supplementary data). In both cases equilibrium is not reached.

At unadjusted $\mathrm{pH}$ an increase in the gas flow rate does not increase the $\mathrm{H}_{\text {stripping }}$ value (Figure S3a, supplementary data). When the $\mathrm{pH}$ was adjusted to 10, however, an increase in the gas flow rate leads to a decrease in the $\mathrm{H}_{\text {stripping }}$ value (Figure S3b, supplementary data), indicating that the biogas is used in a less efficient manner. Figure S2c presents a comparison of non-modified and adjusted $\mathrm{pH}$ : from this it can be concluded that an increase in $\mathrm{pH}$ would lead to a rise in $\mathrm{H}_{\text {stripping. The most efficient }}$ ammonia stripping condition tested is $70{ }^{\circ} \mathrm{C}$ and $\mathrm{pH} 10$ (Figure 4). 


\subsection{Hydrolysis experiment}

To confirm the hypothesis of ammonia generation from $\mathrm{N}_{\text {org }}$ a hydrolysis experiment was conducted where digestate was subjected to temperature/pH increase without stripping.

Heating to $70{ }^{\circ} \mathrm{C}$ without alkali addition (Figure 5) had a clear effect on the nitrogenous material: the TAN concentration increased and $\mathrm{N}_{\text {org }}$ decreased, with the TKN concentration remaining constant during the experiment. There was a decrease in $\mathrm{N}_{\text {org }}$ of 15.3-19.0\% and 25.1-27.8 \% after 22-25 and 94-98 hours, respectively. The $\mathrm{pH}$ showed an initial increase due to $\mathrm{CO}_{2}$ desorption caused by the rise in temperature, then decreased slowly (range 8.37 - 8.07) due to ammonium de-protonation caused by the TAN increase. A mass balance calculation showed the unaccounted-for total nitrogen to be less than $1.6 \%$. The VFA concentration increased rapidly from $140-340 \mathrm{mg} \mathrm{L}^{-1}$ to $6300-6600 \mathrm{mg} \mathrm{L}^{-1}$, which correlated with a decrease in TS from $6.3 \%$ to $5.6 \%$ and in VS from $4.4 \%$ to $3.7 \%$.

At $70{ }^{\circ} \mathrm{C}$ with alkali addition (Figure 5), the TAN profiles showed no increase. This may be due to volatilisation of a small amount of FAN when the digestate is maintained at high temperature, and to a lesser extent during the brief interval before sample analysis, leading to a lower TAN measurement which in turn affects the calculation of $\mathrm{N}_{\text {org }}$. At $70{ }^{\circ} \mathrm{C}$ with $\mathrm{pH} 8.2$ and 9.6, $58.8 \%$ and $97.3 \%$ respectively of the total TAN is in the form of free ammonia. At $4{ }^{\circ} \mathrm{C}$ during storage in a refrigerator, $1.8 \%$ and $31.5 \%$ of the TAN is present as FAN at pH 8.2 and 9. The effect of volatilisation can be seen in the initial TKN values: in all cases the TKN before the $\mathrm{pH}$ increase was greater than after the $\mathrm{pH}$ increase for the same digestate sample. Bonmati and Flotats (2003) also reported that $\mathrm{pH}$ adjustment produced a decrease in TKN and TAN concentration for digested and fresh pig slurry, and attributed this to volatilisation promoted by high temperatures. The VFA concentration in the hydrolysis experiment with alkali addition showed only a small change, from $180-260 \mathrm{mg} \mathrm{L}^{-1}$ to $560 \mathrm{mg} \mathrm{L}^{-1}$. The TS content at the end of the experiment was higher than that in the original sieved digestate due to the addition of lime (initial TS $6.3 \%$, final TS $9.1 \%$ ); the VS destruction rate was lower than in the hydrolysis experiment without $\mathrm{pH}$ adjustment (initial VS $4.4 \%$, final VS $4.1 \%$ ). The unaccounted-for nitrogen in the mass balance was 2.4-3.2 \%, greater than in the experiments without $\mathrm{pH}$ adjustment. This is likely to be due to the fact that the higher $\mathrm{pH}$ promotes the escape of FAN into the gas phase, leading to higher losses and inaccuracy.

In all the experiments conducted the total amount of nitrogen found in the traps was lower than $4 \mathrm{mg}$, showing that this was not a route by which the element left the system.

The results of the hydrolysis experiments suggest that the increase in TAN concentration and the subsequent 'lag' in removal at $55{ }^{\circ} \mathrm{C}$ without $\mathrm{pH}$ modification is in fact due to further production of TAN in the stripping columns, by thermally-promoted hydrolysis of organic nitrogen-containing materials. The ammonia released then contributes to the TAN concentration in the column. 
Time constants obtained for ammonia removal from fresh food waste digestates were much higher than those reported in previous studies using digestates stored for long periods. The results clearly showed that in situ ammonia removal is not feasible under mesophilic or thermophilic conditions. Ammonia stripping was most effective at $70{ }^{\circ} \mathrm{C}$ and $\mathrm{pH} 10$ and under these conditions there was also evidence of further hydrolysis of $\mathrm{N}_{\text {org }}$ leading to an overall increase in ammonia removal. This effect could be quantified by a mass balance approach. The results indicate the feasibility of sidestream stripping and provide kinetic constants for process design.

\section{Acknowledgements}

The authors would like to acknowledge the EU FP7 VALORGAS project 'Valorisation of food waste to biogas' (241334) for supporting this work.

\section{$6 \quad$ References}

1. Angelidaki, I. and Ahring, B. K., 1993. Thermophilic anaerobic digestion of livestock waste: the effect of ammonia. Appl Microbiol and Biotechnol, 38, 560564.

2. Angelidaki, I., Cui, J., Chen, X. and Kaparaju, P., 2006. Operational strategies for thermophilic anaerobic digestion of organic fraction of municipal solid waste in continuously stirred tank reactors. Environ Technol, 27 (8), 855-861.

3. Banks, C. J., Zhang, Y., Jiang, Y. and Heaven, S., 2012. Trace element requirements for stable food waste digestion at elevated ammonia concentrations. Bioresour Technol, 104, 127-135.

4. Bonmati, A. and Flotats, X., 2003. Air stripping of ammonia from pig slurry: characterisation and feasibility as a pre- or post-treatment to mesophilic anaerobic digestion. Waste Manag, 23 (3), 261-272.

5. Borja, R., Sanchez, E. and Weiland, P., 1996. Influence of ammonia concentration on thermophilic anaerobic digestion of cattle manure in upflow anaerobic sludge blanket (UASB) reactors. Process Biochemistry, 31 (5), 477-483.

6. Campos, J. C., Moura, D., Costa, A. P., Yokoyama, L., Araujo, F. V., Cammarota, M. C. and Cardillo, L., 2013. Evaluation of pH, alkalinity and temperature during air stripping process for ammonia removal from landfill leachate. J Environ Sci Health A Tox Hazard Subst Environ Eng, 48 (9), 1105-1113.

7. Cheung, K. C., Chu, L. M. and Wong, M. H., 1995. Ammonia stripping as a pretreatment from landfill leachate. Water, Air, and Soil Pollution, 94, 209-221.

8. De la Rubia, M. A., Walker, M., Heaven, S., Banks, C. J. and Borja, R., 2010. Preliminary trials of in situ ammonia stripping from source segregated domestic food waste digestate using biogas: effect of temperature and flow rate. Bioresour Technol, 101 (24), 9486-9492.

9. Defra, 2010. Optimising Processes for the Stable Operation of Food Waste Digestion (WR1208) - Technical Report.

http://sciencesearch.defra.gov.uk/Default.aspx?Menu=Menu\&Module=More\&Lo cation=None\&Completed=0\&ProjectID=16690, last accessed January 2015.

10. EC, 2010. Future steps in bio-waste management in the European Union Communication from the Commission COM(2010)235 final. http://eurlex.europa.eu/legal-content/EN/ALL/?uri=CELEX:52010DC0235, last accessed January 2015. 
11. Hansen, K. H., Angelidaki, I. and Ahring, B. K., 1998. Anaerobic digestion of swine manure: Inhibition by ammonia. Water Res, 32 (1), 5-12.

12. Hartmann, H. and Ahring, B. K., 2005. A novel process configuration for anaerobic digestion of source-sorted household waste using hyper-thermophilic post-treatment. Biotechnol Bioeng, 90 (7), 830-837.

13. Jiang, X., Hayashi, J., Sun, Z. Y., Yang, L., Tang, Y. Q., Oshibe, H., Osaka, N. and Kida, K., 2013. Improving biogas production from protein-rich distillery wastewater by decreasing ammonia inhibition. Process Biochemistry, 48, 17781784.

14. Kayhanian, M., 1999. Ammonia inhibition in high-solids biogasification: an overview and practical solutions. Environ Technol, 20 (4), 355-365.

15. Kleybocker, A., Liebrich, M., Kasina, M., Kraume, M., Wittmaier, M. and Wurdemann, H., 2012. Comparison of different procedures to stabilize biogas formation after process failure in a thermophilic waste digestion system: Influence of aggregate formation on process stability. Waste Manag, 32 (6), 1120-1130.

16. Laureni, M., Palatsi, J., Llovera, M. and Bonmati, A., 2013. Influence of pig slurry characteristics on ammonia stripping efficiencies and quality of the recovered ammonium-sulfate solution. Journal of Chemical Technology and Biotechnology, 88, 1654-1662.

17. Ledda, C., Schievano, A., Salati, S. and Adani, F., 2013. Nitrogen and water recovery from animal slurries by a new integrated ultrafiltration, reverse osmosis and cold stripping process: a case study. Water Res, 47 (16), 6157-6166.

18. Liu, T. and Sung, S., 2002. Ammonia inhibition on thermophilic aceticlastic methanogens. Water Sci and Technol, 45 (10), 113-120.

19. Perry, R. H. and Green, D. W., 1999. Perry's Chemical Engineers' Handbook. (7th Edition Edition). McGraw-Hill.

20. Nie, H., Jacobi, H. F., Strach, K., Xu, C., Zhou, H., Liebetrau, J., 2015. Monofermentation of chicken manure: ammonia inhibition and recirculation of the digestate. Bioresour Technol, 178, 238-246.

21. Nielsen, H. B. and Ahring, B. K., 2007. Effect of tryptone and ammonia on the biogas process in continuously stirred tank reactors treating cattle manure. Environ Technol, 28 (8), 905-914.

22. Poggi-Varaldo, H. M., Rodríguez-Vázquez, R., Fernández-Villagómez, G. and Esparza-García, F., 1997. Inhibition of mesophilic solid-substrate anaerobic digestion by ammonia nitrogen. Appl Microbiol Biotechnol, 47, 284-291.

23. Rintala, J. A. and Ahring, B. K., 1994. A two stage thermophilic anaerobic process for the treatment of source sorted household solid waste. Biotechnology Letters, 16 (10), 1097-1102.

24. Schnürer, A. and Nordberg, A., 2008. Ammonia, a selective agent for methane production by syntrophic acetate oxidation at mesophilic temperature. Water Sci Technol, 57 (5), 735-740.

25. Serna-Maza, A., Heaven, S. and Banks, C. J., 2014. Ammonia removal in food waste anaerobic digestion using a side-stream stripping process. Bioresour Technol, 152, 307-315.

26. Tampio, E., Ervasti, S., Paavola, T., Heaven, S., Banks, C., and Rintala, J., 2014. Anaerobic digestion of autoclaved and untreated food waste. Waste Manag, 34 (2), 370-377. 
27. VALORGAS, 2013. Technical solutions to allow digesters operating on high nitrogen food waste to achieve the maximum energy yield. Deliverable D4.6. http://www.valorgas.soton.ac.uk/deliverables.htm; last accessed April 2014.

28. Walker, M., Iyer, K., Heaven, S. and Banks, C. J., 2011. Ammonia removal in anaerobic digestion by biogas stripping: An evaluation of process alternatives using a first order rate model based on experimental findings. Chemical Engineering Journal, 178, 138-145.

29. Walker, M., Zhang, Y., Heaven, S. and Banks, C., 2009. Potential errors in the quantitative evaluation of biogas production in anaerobic digestion processes. Bioresour Technol, 100, 6339-6346.

30. Yirong, C., Banks, C. J. and Heaven, S., 2013a. Comparison of mesophilic and thermophilic anaerobic digestion of food waste. In: AD13 Recovering (bio) Resources for the World. Santiago de Compostela. IWA.

31. Yirong, C., Banks, C. J. and Heaven, S., 2013b. Effect of ammonia nitrogen on thermophilic anaerobic digestion of food waste. In: 21st European Biomass Conference and Exhibition Copenhagen (Denmark).

32. Zeng, L., Mangan, C. and Li, X., 2006. Ammonia recovery from anaerobically digested cattle manure by steam stripping. Water Sci and Technol, 54 (8), 137.

33. Zhang, Y., Banks, C. J. and Heaven, S., 2012. Co-digestion of source segregated domestic food waste to improve process stability. Bioresour Technol, 114, 168178.

34. Zhang, L. and Jahng, D., 2010. Enhanced anaerobic digestion of piggery wastewater by ammonia stripping: effects of alkali types. Hazard Mater, 182 (13), 536-543.

35. Zhang, L., Lee, Y. W. and Jahng, D., 2011. Ammonia stripping for enhanced biomethanization of piggery wastewater. Hazard Mater, 199-200, 36-42. 


\section{Figure Captions}

Figure 1 Details of experimental set-up: (a) 75-L CSTR digesters. 1 Feed port, 2 stirrer motor, 3 heater, 4 heating coil, 5 digestate outlet; 6 gas meter in line with gasimpermeable bag for gas collection at atmospheric pressure (b) diagram of batch ammonia stripping system. E-1 peristaltic pump, E-2 stripping column with heating jacket, E-3 condensate trap, E-4 water trap, E-5 acid trap, E-6 heater.

Figure 2 TAN removal profile in all batch stripping runs

Figure 3 Nitrogen mass balance in the stripping column

Figure 4 Efficiency $E$ values vs temperature with and without $\mathrm{pH}$ adjustment

Figure 5 Hydrolysis results obtained at $70{ }^{\circ} \mathrm{C}$ : (a) TAN profile, (b) TKN profile, (c) $\mathrm{N}_{\text {org }}$ profile, (d) $\mathrm{N}_{\text {org }}$ reduction, (e) VFA profile, (f) $\mathrm{pH}$ profile. 
Table 1 Inoculum, SS-DFW and digestate characteristics

\begin{tabular}{|c|c|c|c|c|}
\hline \multicolumn{5}{|l|}{ Inoculum characteristics } \\
\hline & \multicolumn{2}{|c|}{$\mathbf{R}_{1}$} & \multicolumn{2}{|c|}{$\mathbf{R}_{2}$} \\
\hline pH & \multicolumn{2}{|c|}{$8.40 \pm 0.04$} & \multicolumn{2}{|c|}{$8.34 \pm 0.04$} \\
\hline 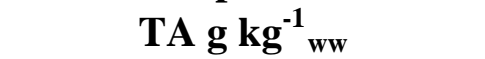 & \multicolumn{2}{|c|}{$16.98 \pm 0.06$} & \multicolumn{2}{|c|}{$16.89 \pm 0.06$} \\
\hline PA g kg ${ }^{-1}{ }_{w w}$ & \multicolumn{2}{|c|}{$12.86 \pm 0.03$} & \multicolumn{2}{|c|}{$12.81 \pm 0.03$} \\
\hline IA $\mathrm{g} \mathrm{kg}^{-1}{ }_{\mathrm{ww}}$ & \multicolumn{2}{|c|}{$3.59 \pm 0.09$} & \multicolumn{2}{|c|}{$3.46 \pm 0.09$} \\
\hline TAN g N kg ${ }^{-1}{ }_{w w}$ & \multicolumn{2}{|c|}{$3.28 \pm 0.09$} & \multicolumn{2}{|c|}{$3.42 \pm 0.09$} \\
\hline TKN g N kg ${ }^{-1}{ }_{w w}$ & \multicolumn{2}{|c|}{$5.17 \pm 0.02$} & \multicolumn{2}{|c|}{$5.09 \pm 0.04$} \\
\hline TS g kg-1 & \multicolumn{2}{|c|}{$35.5 \pm 0.7$} & \multicolumn{2}{|c|}{$36.5 \pm 0.7$} \\
\hline VS g kg-1 & \multicolumn{2}{|c|}{$23.9 \pm 0.5$} & \multicolumn{2}{|c|}{$24.7 \pm 0.5$} \\
\hline VFA (100\% acetic) $\mathbf{~ m g ~ L ~}^{-1}$ & \multicolumn{2}{|c|}{$130 \pm 5$} & \multicolumn{2}{|c|}{$125 \pm 5$} \\
\hline Co mg L $\mathrm{L}^{-1}$ & \multicolumn{2}{|r|}{1.51} & \multicolumn{2}{|c|}{1.6} \\
\hline Fe mg L $L^{-1}$ & \multicolumn{2}{|r|}{62.31} & \multicolumn{2}{|c|}{105.18} \\
\hline Mo ${\text { mg } L^{-1}}^{-1}$ & \multicolumn{2}{|r|}{0.54} & \multicolumn{2}{|c|}{0.5} \\
\hline Ni mg L ${ }^{-1}$ & \multicolumn{2}{|r|}{2.36} & & 4.1 \\
\hline Se $\mathbf{m g ~ L}^{-1}$ & & 0.08 & & .09 \\
\hline Characteristics of the SS-DF & FW batches & & & \\
\hline Eod wacto batch & Start & End & TS & VS \\
\hline Food waste Datch & ding day) & (feeding day) & $\left(\mathrm{g} \mathrm{kg}^{-1}\right)$ & $\left(\mathrm{g} \mathrm{kg}^{-1}\right)$ \\
\hline 1 & 0 & 142 & $258.9 \pm 0.1$ & $240.0 \pm 0.3$ \\
\hline 2 & 143 & 190 & $235.2 \pm 1.0$ & $217.4 \pm 0.6$ \\
\hline 3 & 191 & 235 & $237.6 \pm 3.8$ & $219.1 \pm 3.4$ \\
\hline 4 & 236 & 265 & $249.2 \pm 5.8$ & $231.0 \pm 6.3$ \\
\hline 5 & 266 & 323 & $232.4 \pm 1.7$ & $219.5 \pm 2.5$ \\
\hline 6 & 324 & 456 & $237.3 \pm 2.5$ & $223.9 \pm 2.3$ \\
\hline 7 & 457 & 462 & $246.2 \pm 2.4$ & $228.1 \pm 4.4$ \\
\hline Digestate characteristics (a) & verage at ste & ady state) & & \\
\hline & & $\mathbf{R}_{1}$ & & $\mathbf{R}_{2}$ \\
\hline & Average & Deviation \% & Average & Deviation \% \\
\hline $\mathbf{p H}$ & 7.91 & 0.7 & 7.89 & 0.7 \\
\hline$T A g_{~ k g}{ }^{-1}{ }_{w w}$ & 24.2 & 2.2 & 23.6 & 2.1 \\
\hline PA $g_{\text { kg }}^{-1}{ }_{w w}$ & 18.4 & 4.7 & 17.6 & 4.5 \\
\hline IA k kg $^{-1} w w$ & 5.2 & 12.9 & 5.2 & 9.6 \\
\hline${ }^{*}$ TKN mg N kg ${ }^{-1}{ }_{w w}$ & 8780 & 0.4 & 8720 & 1 \\
\hline TAN mg $\mathrm{N} \mathrm{kg}^{-1}{ }_{\mathrm{ww}}$ & 4907 & 1.2 & 4808 & 1.5 \\
\hline TS g kg $^{-1}$ & 65.84 & 1.1 & 66.68 & 1.4 \\
\hline VS g kg $\mathbf{~}^{-1}$ & 48 & 1.3 & 48.51 & 1.5 \\
\hline VFA mg $L^{-1}$ & 152 & - & 143 & - \\
\hline
\end{tabular}

\footnotetext{
${ }^{*}$ At the end of the experiment
} 
Table 2 Summary of ammonia stripping experimental results

\begin{tabular}{|c|c|c|c|c|c|c|c|c|c|c|c|}
\hline Run & $\begin{array}{c}\mathrm{T} \\
\left({ }^{\circ} \mathrm{C}\right)\end{array}$ & initial $\mathbf{p}$ & & $\begin{array}{c}\text { flow } \\
\left(\mathrm{L} \text { min }^{-1} L^{-1}\right)\end{array}$ & 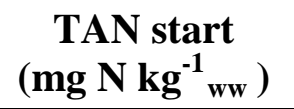 & $\begin{array}{c}\text { TAN end } \\
\left(\mathrm{mg} \mathrm{N} \mathrm{kg}^{-1}{ }_{w w}\right)\end{array}$ & $\begin{array}{c}\text { TAN removal } \\
(\%)\end{array}$ & $\begin{array}{c}\text { Time } \\
\text { (h) }\end{array}$ & $\begin{array}{c}\tau \\
\text { (h) }\end{array}$ & $\mathbf{R}^{2}$ & equation \\
\hline 1 & 35 & \multirow{7}{*}{$\mathrm{n} / \mathrm{a}$} & 8.27 & 0.125 & 4650 & 4780 & - & 383 & - & - & no stripped \\
\hline 2 & 55 & & 8.04 & 0.125 & 4730 & 2440 & 48.4 & 836 & 1111 & 0.95 & $\mathrm{y}=5374 \mathrm{e}^{-0.0009 x}$ \\
\hline 3 & 55 & & 7.90 & 0.250 & 4930 & 3180 & 35.2 & 524 & 1111 & 0.98 & $y=5242 e^{-0.0009 x}$ \\
\hline 4 & 55 & & 7.90 & 0.250 & 4930 & 2790 & 43.2 & 524 & 833 & 0.98 & $y=5216 e^{-0.0012 x}$ \\
\hline 5 & 70 & & 8.30 & 0.125 & 4560 & 1890 & 58.5 & 243 & 222 & 0.98 & $y=4522 e^{-0.0045 x}$ \\
\hline 6 & 70 & & 7.90 & 0.250 & 4900 & 2880 & 57.0 & 142 & 161 & 0.92 & $y=4383 e^{-0.0062 x}$ \\
\hline 7 & 70 & & 7.90 & 0.125 & 4900 & 2370 & 52 & 234 & 278 & 0.94 & $y=5090 e^{-0.0036 x}$ \\
\hline 8 & 35 & $10(\mathrm{NaOH})$ & 10.01 & 0.125 & 4020 & 2740 & 31.9 & 403 & 909 & 0.93 & $y=4111 e^{-0.0011 x}$ \\
\hline 9 & 35 & \multirow{3}{*}{$10(\mathrm{CaO})$} & 9.72 & 0.125 & 4380 & 2930 & 33.0 & 403 & 909 & 0.94 & $y=4342 e^{-0.0011 x}$ \\
\hline 10 & 35 & & 9.69 & 0.250 & 4770 & 2940 & 38.3 & 307 & 714 & 0.82 & $y=4248 e^{-0.0014 x}$ \\
\hline 11 & 35 & & 9.69 & 0.250 & 4770 & 3030 & 36.4 & 307 & 714 & 0.82 & $y=4316 e^{-0.0014 x}$ \\
\hline 12 & 55 & \multirow{4}{*}{$10(\mathrm{NaOH})$} & 9.98 & 0.125 & 4120 & 470 & 88.6 & 427 & 189 & 0.96 & $y=4148 e^{-0.0053 x}$ \\
\hline 13 & 55 & & 9.95 & 0.250 & 4350 & 330 & 92.5 & 382 & 147 & 0.98 & $y=4622 e^{-0.0068 x}$ \\
\hline 14 & 70 & & 9.99 & 0.125 & 3460 & 420 & 87.8 & 93 & 44 & 0.97 & $y=4.039 e^{-0.0226 x}$ \\
\hline 15 & 70 & & 9.99 & 0.250 & 3460 & 280 & 92.1 & 93 & 37 & 0.98 & $\mathrm{y}=3147 \mathrm{e}^{-0.0267 x}$ \\
\hline 16 & 70 & \multirow{2}{*}{$10(\mathrm{CaO})$} & 9.76 & 0.125 & 4180 & 620 & 85.1 & 120 & 62 & 0.98 & $\mathrm{y}=4709 \mathrm{e}^{-0.0162 \mathrm{x}}$ \\
\hline 17 & 70 & & 9.88 & 0.250 & 4240 & 850 & 79.9 & 120 & 57 & 0.95 & $y=3742 e^{-0.0175 x}$ \\
\hline
\end{tabular}

n/a: not adjusted 
$\underline{\text { Table } 3 \text { Comparison of time constants }\left(\tau_{\text {low }} / \tau_{\text {high }}\right) \text { for different experimental conditions }}$

\begin{tabular}{|c|c|c|c|c|}
\hline \multicolumn{5}{|c|}{ Temperature } \\
\hline & \multicolumn{2}{|c|}{$0.125 \mathrm{~L} \mathrm{~min}^{-1} \mathrm{~L}^{-1}$} & \multicolumn{2}{|c|}{$0.250 \mathrm{~L} \mathrm{~min}^{-1} \mathrm{~L}^{-1}$} \\
\hline & pH n/a & pH 10 & pH n/a & pH 10 \\
\hline $35{ }^{\circ} \mathrm{C}$ to $55^{\circ} \mathrm{C}$ & - & 4.8 & - & 4.9 \\
\hline $55^{\circ} \mathrm{C}$ to $70{ }^{\circ} \mathrm{C}$ & 4.4 & 3.6 & 6 & 3.1 \\
\hline \multicolumn{5}{|c|}{$p H(n / a$ to $p H ~ 10)$} \\
\hline & 0.12 & $\mathbf{L}^{-1}$ & \multicolumn{2}{|c|}{$0.250 \mathrm{~L} \mathrm{~min}^{-1} \mathrm{~L}^{-1}$} \\
\hline $35^{\circ} \mathrm{C}$ & & & \multicolumn{2}{|c|}{-} \\
\hline $55^{\circ} \mathrm{C}$ & & & \multicolumn{2}{|c|}{6.6} \\
\hline $70^{\circ} \mathrm{C}$ & & & \multicolumn{2}{|c|}{3.4} \\
\hline \multicolumn{5}{|c|}{ Flow $\left(0.125 \mathrm{~L} \mathrm{~min}^{-1} \mathrm{~L}^{-1}\right.$ to $\left.0.250 \mathrm{~L} \mathrm{~min}^{-1} \mathrm{~L}^{-1}\right)$} \\
\hline & \multicolumn{2}{|c|}{ pH n/a } & \multicolumn{2}{|c|}{ pH 10} \\
\hline $35^{\circ} \mathrm{C}$ & \multicolumn{2}{|c|}{-} & \multicolumn{2}{|c|}{1.3} \\
\hline $55^{\circ} \mathrm{C}$ & \multicolumn{2}{|c|}{1.1} & \multicolumn{2}{|c|}{1.3} \\
\hline $70{ }^{\circ} \mathrm{C}$ & \multicolumn{2}{|c|}{1.6} & \multicolumn{2}{|c|}{1.1} \\
\hline
\end{tabular}

$\mathrm{pH}$ n/a: $\mathrm{pH}$ not adjusted 
Table $4 \mathrm{H}_{\text {stripping }}$ values and experimental constants for $\mathrm{H}_{\text {stripping }}$ calculation

\begin{tabular}{cccccccccc}
\hline Run & $\mathbf{A}$ & $\mathbf{B}$ & $\mathbf{R}^{2}$ & $\mathbf{A}^{\mathbf{\prime}}$ & $\mathbf{B}^{\prime}$ & $\mathbf{R}^{\mathbf{2}}$ & $\mathbf{C}$ & $\mathbf{D}$ & $\mathbf{H}_{\text {stripping }}$ \\
\hline 1 & & & & & & & & & unstripped \\
2 & 5374 & 0.0009 & 0.9492 & 3117 & 0.0013 & 0.7445 & 0.000468 & 1.991 & 0.750 \\
3 & 5242 & 0.0009 & 0.9791 & 1833 & 0.0020 & 0.7721 & 0.000604 & 0.999 & 0.891 \\
4 & 5216 & 0.0012 & 0.9767 & 1867 & 0.0024 & 0.8310 & 0.000823 & 1.009 & 1.157 \\
5 & 4522 & 0.0045 & 0.9746 & 3581 & 0.0070 & 0.9725 & 0.003546 & 2.005 & 3.244 \\
6 & 4383 & 0.0062 & 0.9223 & 2811 & 0.0140 & 0.9235 & 0.003023 & 0.998 & 3.329 \\
7 & 5090 & 0.0036 & 0.9402 & 3118 & 0.0055 & 0.8310 & 0.00271 & 2.004 & 3.276 \\
8 & 4111 & 0.0011 & 0.9297 & 3278 & 0.0022 & 0.9208 & 0.00046 & 2.027 & 0.400 \\
9 & 4342 & 0.0011 & 0.9351 & 3181 & 0.0022 & 0.8880 & 0.001012 & 2.085 & 0.585 \\
10 & 4415 & 0.0016 & 0.8511 & 3918 & 0.0067 & 0.9550 & 0.000384 & 1.000 & 0.162 \\
11 & 4316 & 0.0014 & 0.8233 & 3759 & 0.0068 & 0.9686 & 0.000415 & 1.004 & 0.150 \\
12 & 4148 & 0.0053 & 0.9582 & 3943 & 0.0055 & 0.9611 & 0.000947 & 2.004 & 2.165 \\
13 & 4622 & 0.0068 & 0.9775 & 4435 & 0.0080 & 0.9856 & 0.001098 & 1.002 & 1.517 \\
14 & 4039 & 0.0226 & 0.9725 & 3957 & 0.0228 & 0.9738 & 0.002622 & 1.987 & 9.023 \\
15 & 3147 & 0.0267 & 0.9799 & 3083 & 0.0271 & 0.9802 & 0.002169 & 0.999 & 5.356 \\
16 & 4709 & 0.0162 & 0.9843 & 4542 & 0.0162 & 0.9836 & 0.002507 & 1.987 & 6.612 \\
17 & 3742 & 0.0175 & 0.9539 & 3412 & 0.0194 & 0.9209 & 0.002791 & 0.993 & 4.136 \\
\hline
\end{tabular}


Figure 1.

a

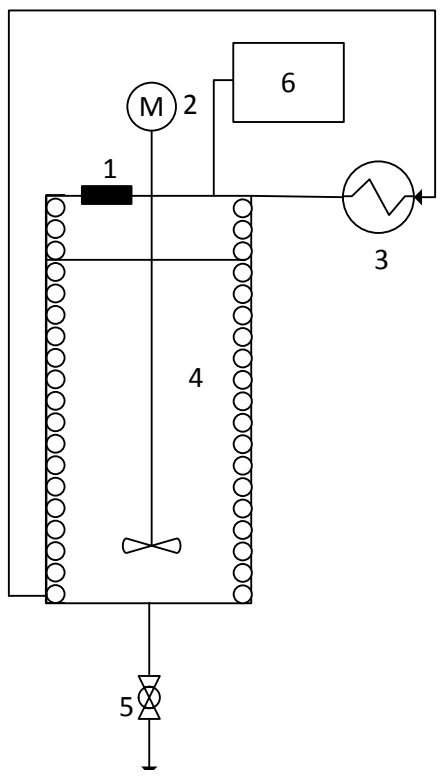

b

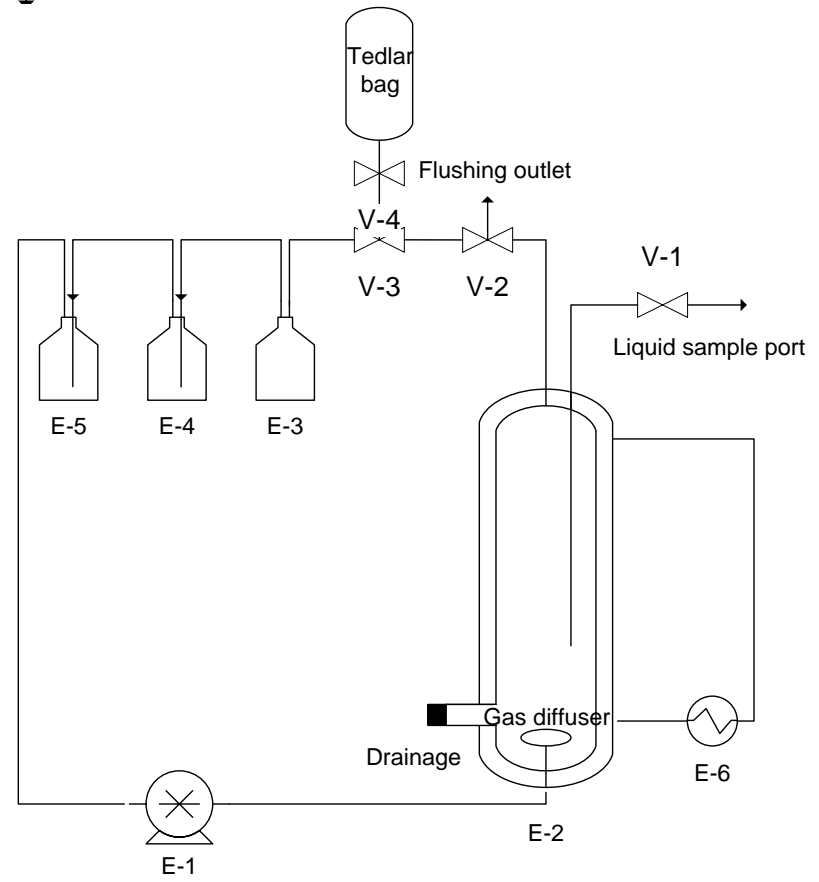


Figure 2.

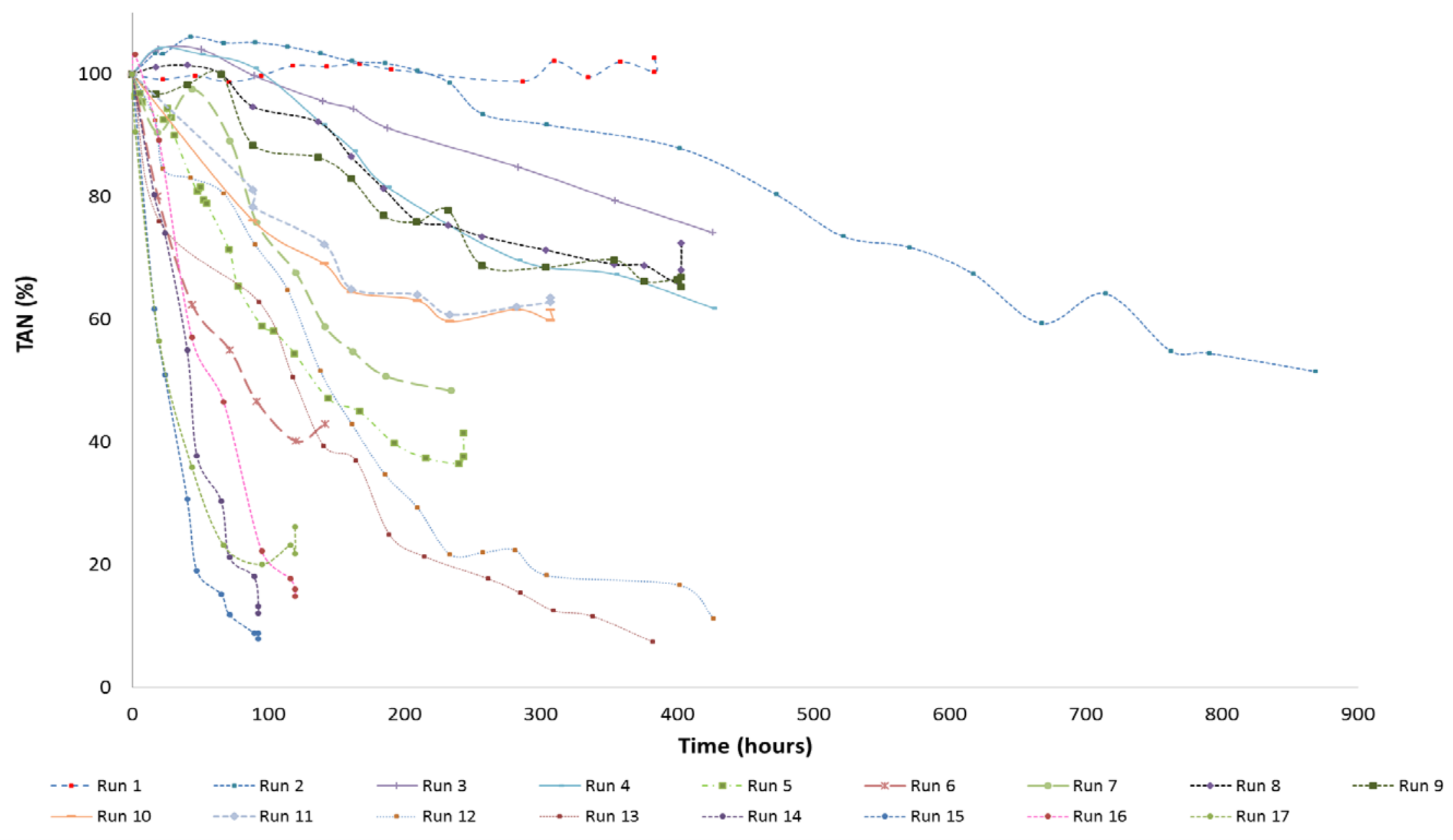


Figure 3.

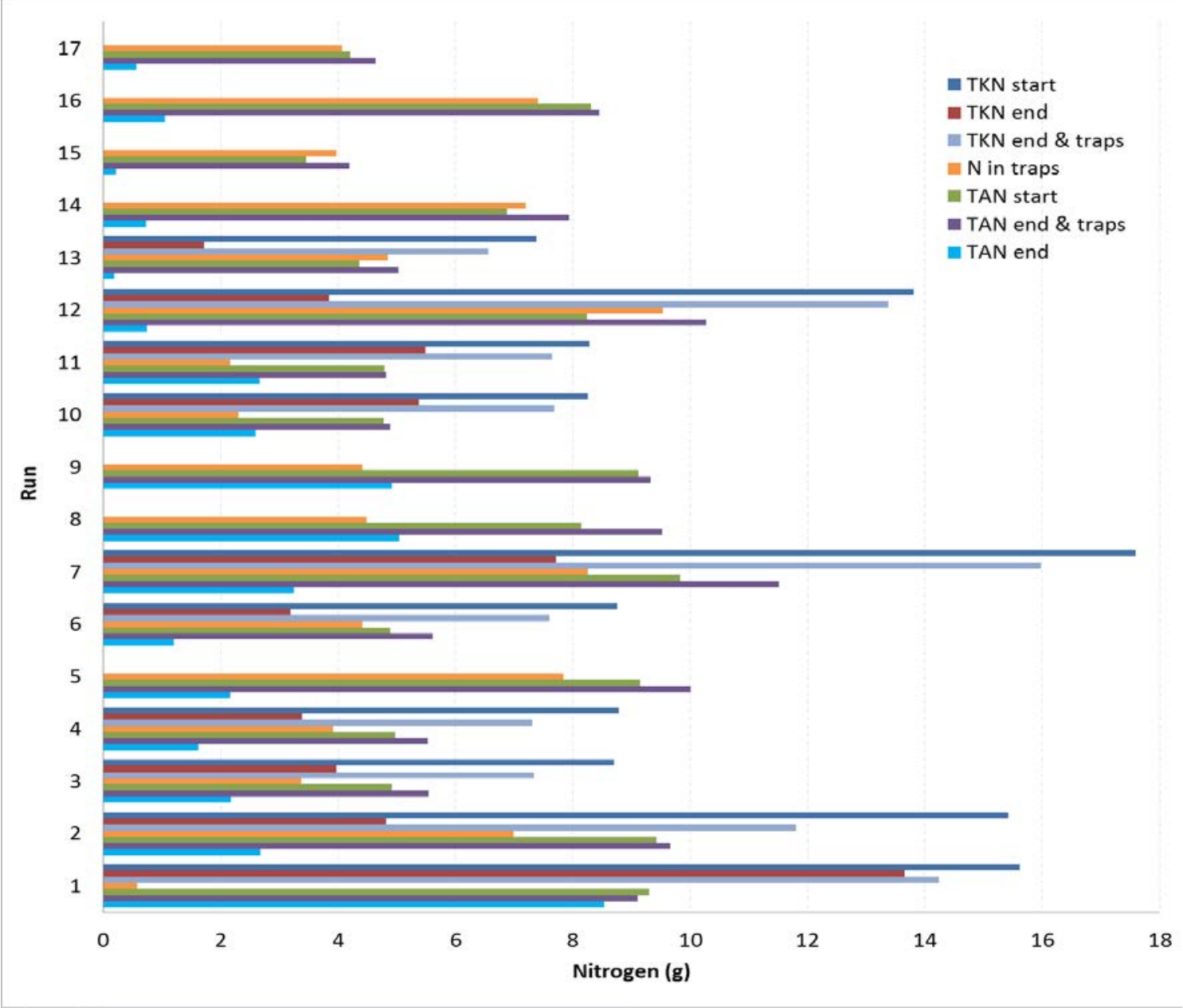


Figure 4.

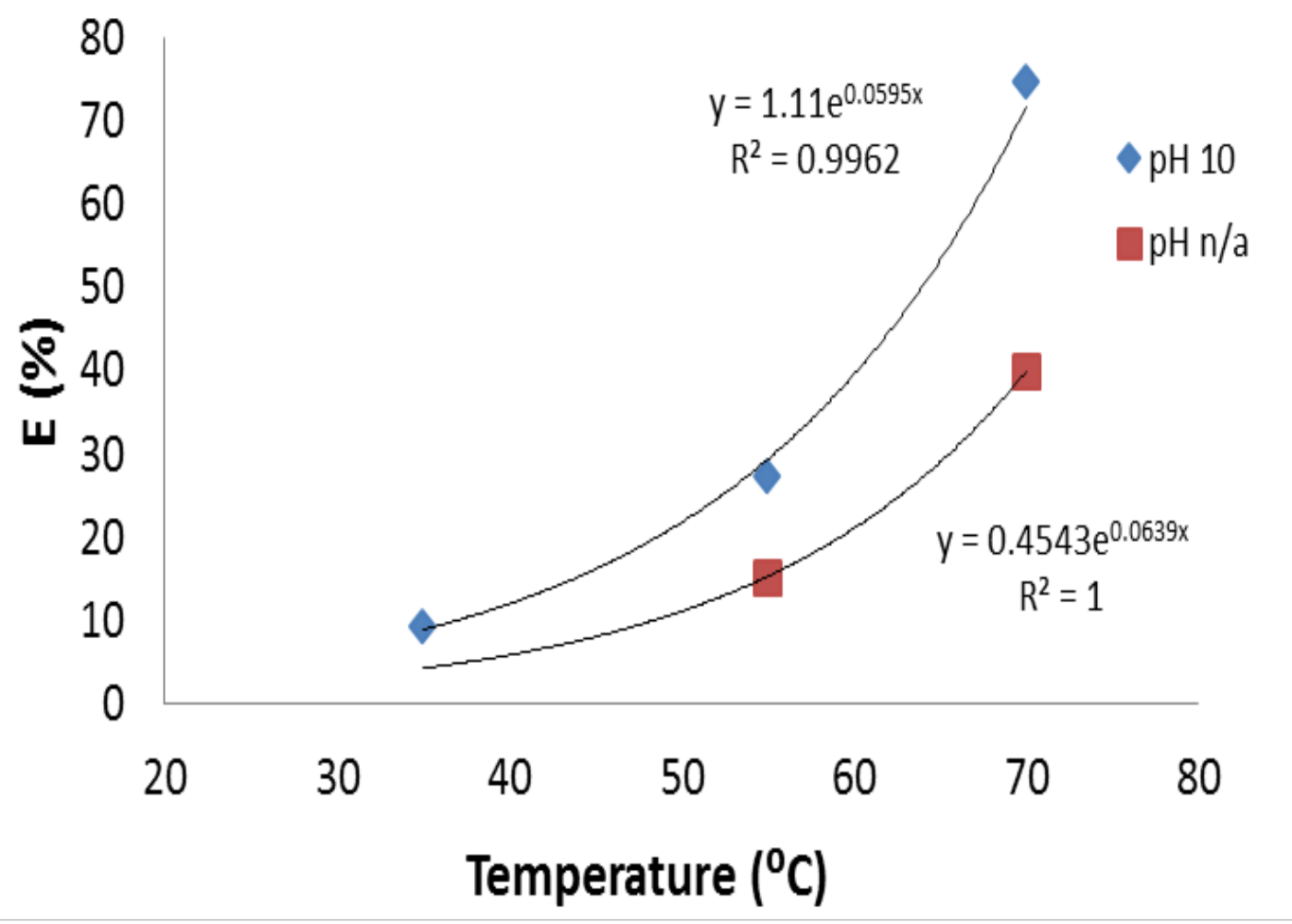




\section{Figure 5.}
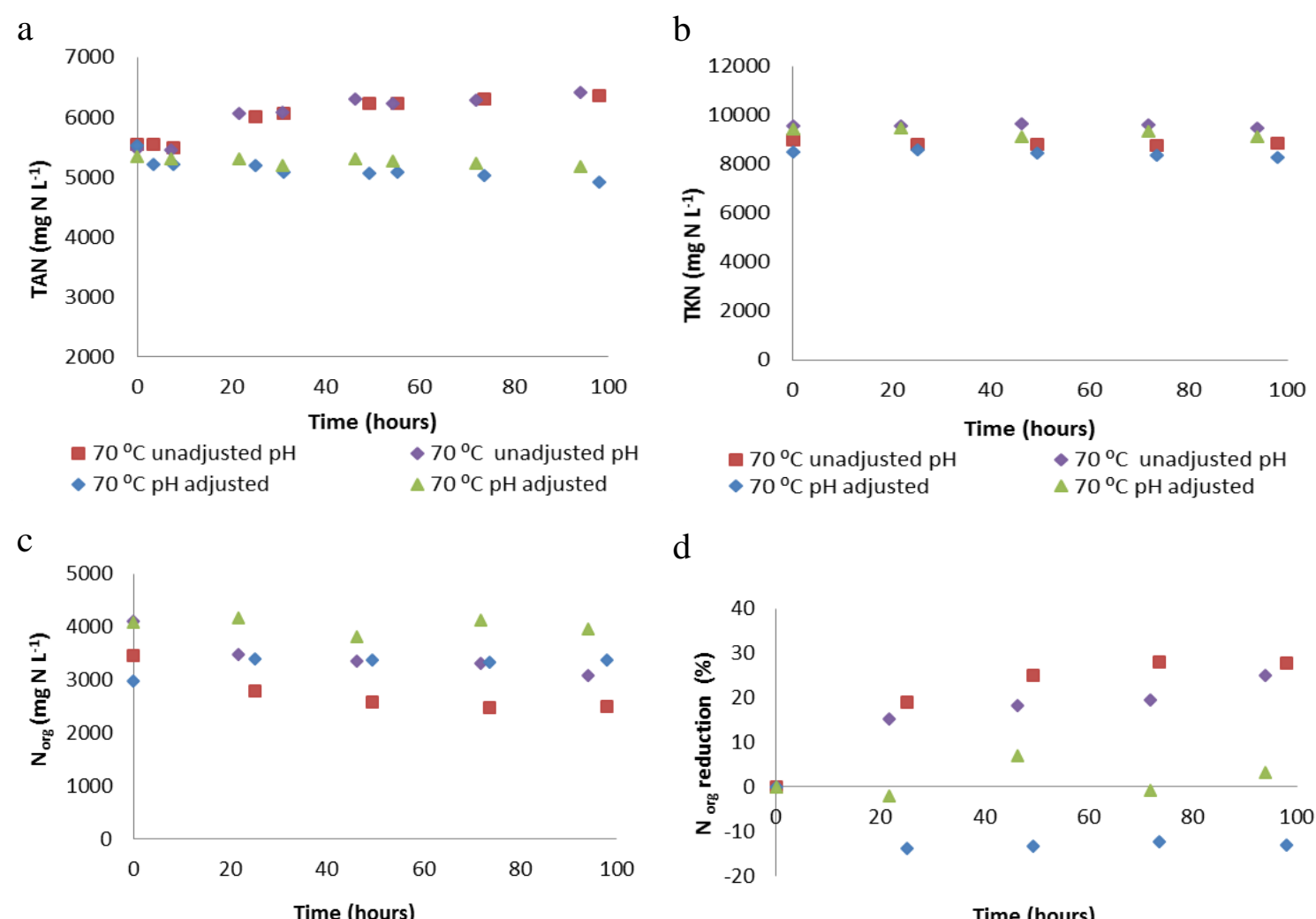

d
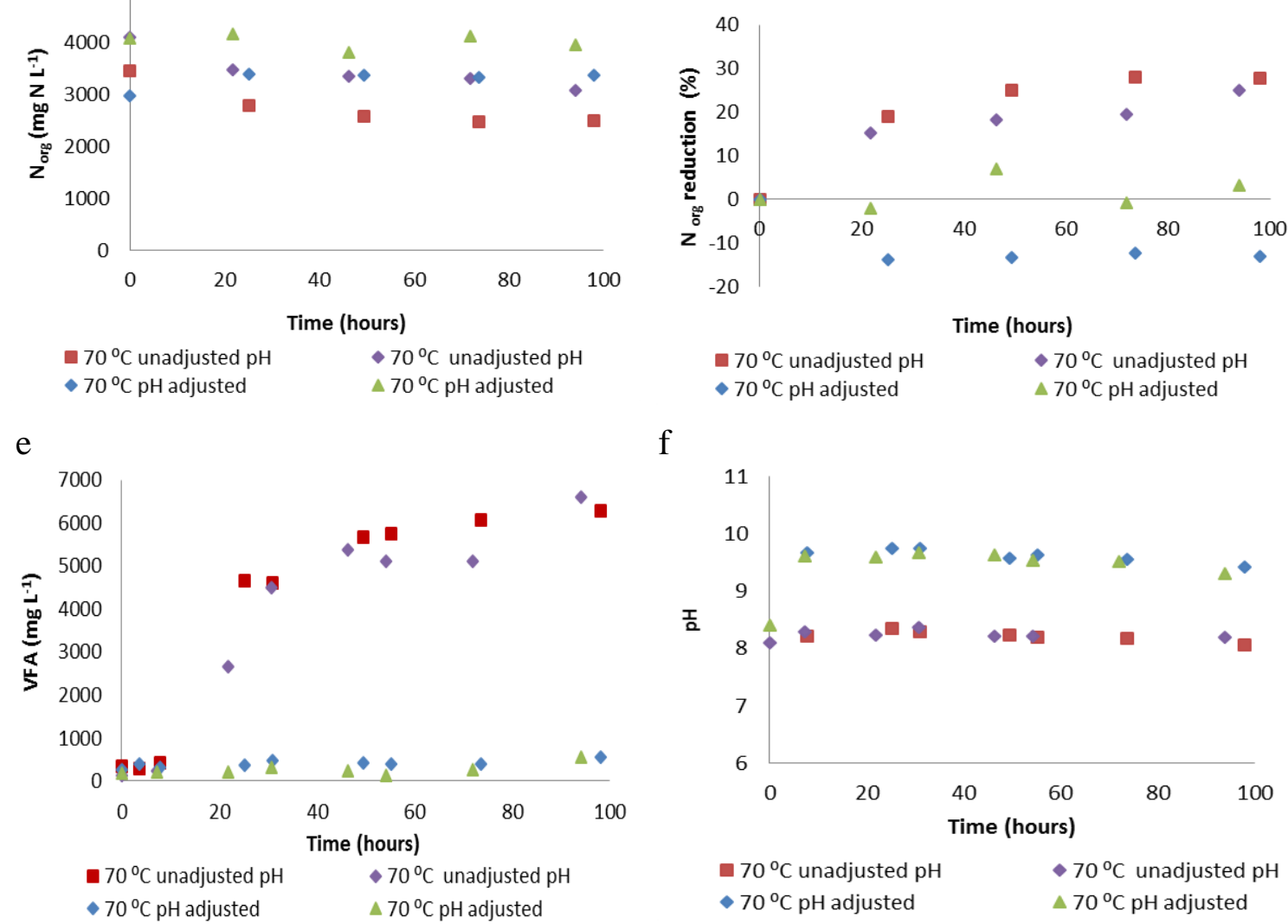

f

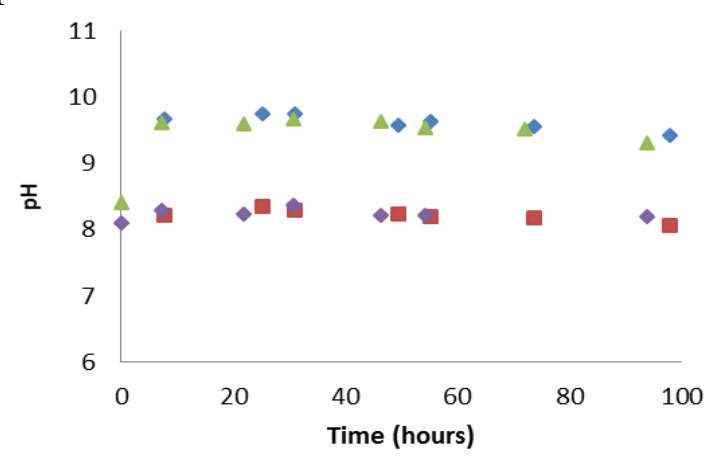

$\begin{array}{ll}\square 70{ }^{\circ} \mathrm{C} \text { unadjusted } \mathrm{pH} & \diamond 70^{\circ} \mathrm{C} \text { unadjusted } \mathrm{pH} \\ \bullet 70^{\circ} \mathrm{C} \mathrm{pH} \text { adjusted } & \triangle 70^{\circ} \mathrm{C} \mathrm{pH} \text { adjusted }\end{array}$ 


\section{Supplementary materials}

Table S1. Digestate characteristics at the beginning of the experiment

\begin{tabular}{|c|c|c|c|c|c|c|}
\hline $\mathbf{N}_{\text {exp }}$ & $\begin{array}{l}\text { Digestate } \\
\text { mass (kg) }\end{array}$ & $\begin{array}{c}\text { TAN start } \\
\left(\mathrm{mg} \mathrm{N} \mathrm{kg}^{-1}{ }_{\text {ww }}\right)\end{array}$ & $\begin{array}{c}\text { TKN start } \\
\left(\mathrm{mg} \mathrm{N} \mathrm{kg}^{-1}{ }_{\text {ww }}\right)\end{array}$ & $\begin{array}{c}N_{\text {org }} \\
\left(\mathrm{mg} \mathrm{N} \mathrm{kg}^{-1}{ }_{\text {ww }}\right)\end{array}$ & $\mathbf{N}_{\text {samples }}{ }^{*}$ & $\begin{array}{r}\mathrm{N}_{\text {rem }}{ }^{+} \\
(\%)\end{array}$ \\
\hline 1 & 1.997 & 4654 & 7820 & 3166 & & - \\
\hline 2 & 1.991 & 4732 & 7747 & 3015 & 16 & - \\
\hline 3 & 0.999 & 4925 & 8706 & 3781 & 12 & - \\
\hline 4 & 1.009 & 4925 & 8706 & 3781 & 12 & - \\
\hline 5 & 2.005 & 4561 & - & - & 23 & - \\
\hline 6 & 0.998 & 4904 & 8779 & 3875 & 6 & - \\
\hline 7 & 2.004 & 4904 & 8779 & 3875 & 9 & - \\
\hline 8 & 2.027 & 4018 & - & - & 15 & 17.4 \\
\hline 9 & 2.085 & 4376 & - & - & 15 & 10.0 \\
\hline 10 & 1.000 & 4771 & 8259 & 3488 & 8 & 21.3 \\
\hline 11 & 1.004 & 4771 & 8259 & 3488 & 8 & 21.3 \\
\hline 12 & 2.004 & 4116 & 6893 & 2777 & 16 & 12.5 \\
\hline 13 & 1.002 & 4349 & 7370 & 3022 & 7 & 9.6 \\
\hline 14 & 1.987 & 3463 & - & - & 8 & 24.5 \\
\hline 15 & 0.999 & 3463 & - & - & 8 & 24.5 \\
\hline 16 & 1.987 & 4183 & - & - & 7 & 13.1 \\
\hline 17 & 0.993 & 4241 & - & - & 7 & 11.9 \\
\hline
\end{tabular}

Initial digestate amount in the column

* Total number of samples taken from the batch experiment

${ }^{+} \mathrm{N}$ loss during the $\mathrm{pH}$ increase procedure 
Table S2. Digestate characteristics at the end of the experiment

\begin{tabular}{|c|c|c|c|c|c|c|c|}
\hline $\mathbf{N}_{\text {exp }}$ & $\begin{array}{l}\text { Solid }^{*} \\
\text { (kg) }\end{array}$ & $\begin{array}{r}M_{\text {Dig }} \\
(\mathbf{k g})\end{array}$ & $\begin{array}{c}\text { TAN end } \\
\left(\mathrm{mg} \mathrm{N} \mathrm{kg}^{-1}{ }_{\text {ww }}\right)\end{array}$ & $\begin{array}{c}\text { TKN end } \\
\left(\mathrm{mg} \mathrm{N} \mathrm{kg}^{-1}{ }_{w w}\right)\end{array}$ & $\begin{array}{c}N_{\text {org }} \\
\left(\mathrm{mg} \mathrm{N} \mathrm{kg}^{-1}{ }_{\text {ww }}\right)\end{array}$ & $\begin{array}{l}\mathrm{N} \text { in } \\
\text { traps }^{+}( \\
\mathrm{g})\end{array}$ & 1 \\
\hline 1 & - & 1.785 & 4779 & 7648 & 2869 & 0.58 & 0 \\
\hline 2 & 0.2635 & 1.094 & 2440 & 4403 & 1963 & 6.99 & 0 \\
\hline 3 & 0 & 0.683 & 3184 & 5815 & 2630 & 3.37 & 0 \\
\hline 4 & 0 & 0.578 & 2792 & 5860 & 3069 & 3.92 & 0 \\
\hline 5 & - & 1.142 & 1893 & - & - & 7.84 & 0 \\
\hline 6 & 0 & 0.570 & 2109 & 5594 & 3486 & 4.41 & 0 \\
\hline 7 & 0 & 1.370 & 2374 & 5633 & 3259 & 8.26 & 0 \\
\hline 8 & 0 & 1.841 & 2737 & - & - & 4.48 & 0 \\
\hline 9 & 0.1387 & 1.677 & 2929 & - & - & 4.41 & 0 \\
\hline 10 & 0 & 0.882 & 2941 & 6101 & 3160 & 2.30 & 0 \\
\hline 11 & 0 & 0.876 & 3034 & 6267 & 3233 & 2.16 & 0 \\
\hline 12 & 0.0215 & 1.600 & 467 & 2407 & 1940 & 9.53 & 0 \\
\hline 13 & 0.0125 & 0.582 & 325 & 2945 & 2620 & 4.84 & 0 \\
\hline 14 & - & 1.744 & 421 & - & - & 7.20 & 0 \\
\hline 15 & - & 0.798 & 275 & - & - & 3.97 & 0 \\
\hline 16 & - & 1.687 & 624 & - & - & 7.40 & 0 \\
\hline 17 & - & 0.659 & 854 & - & - & 4.07 & 0 \\
\hline
\end{tabular}

${ }^{*}$ Mass of solid found in the column at end of run

${ }^{\wedge}$ Mass of digestate in the column at end of run

${ }^{+}$Total mass of $\mathrm{N}$ found in the condensate, water trap and acid traps

- Mass unrecovered from the experiment, calculated value from mass balance:

Unrecovered matter $=$

Mass $_{\text {dig in }}-$ Mass $_{\text {dig out }}-$ Mass $_{\text {sample }}-$ Mass gain traps - Solid $_{\text {recovered }}$ 


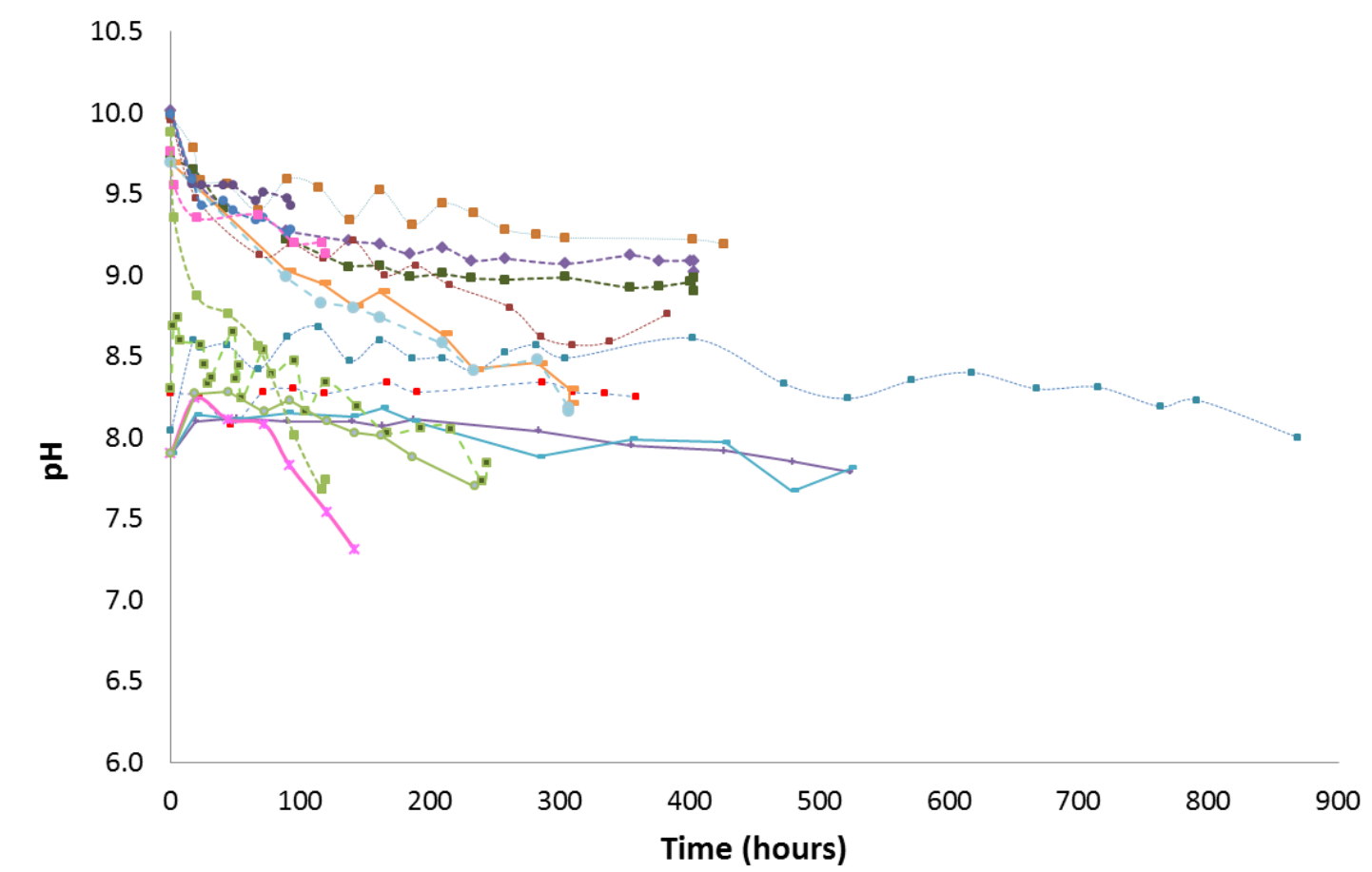

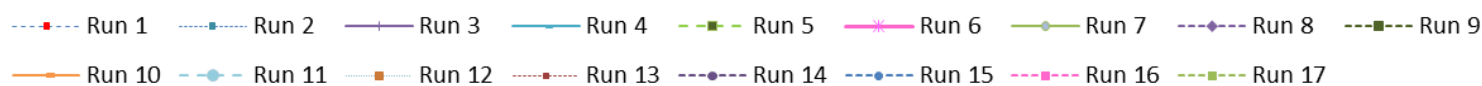

Figure S1. Digestate $\mathrm{pH}$ profile in ammonia stripping experiments 
$\mathrm{a}$

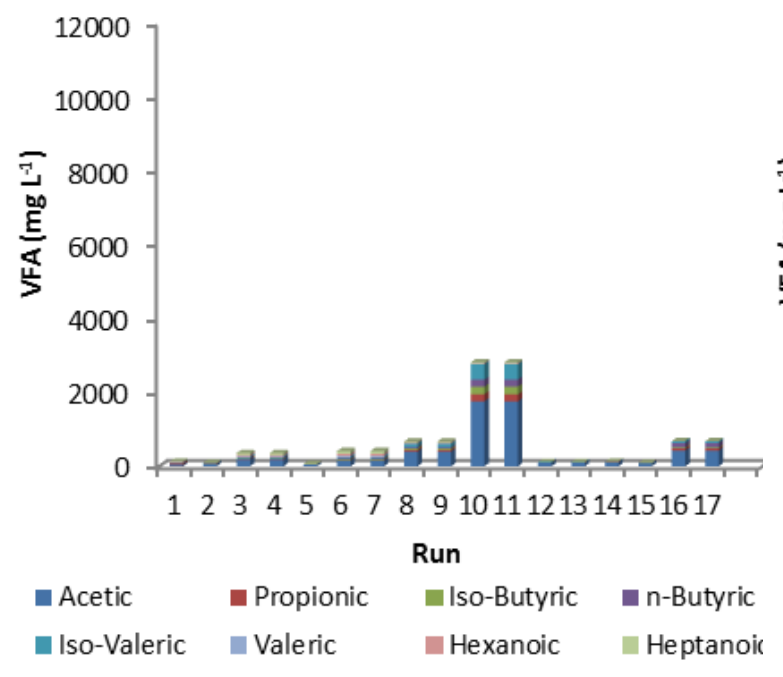

b

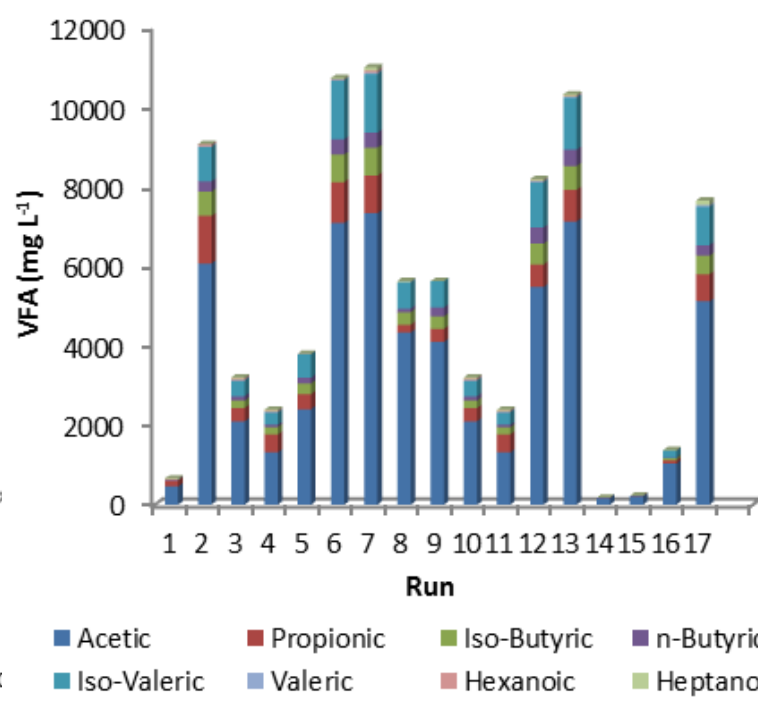

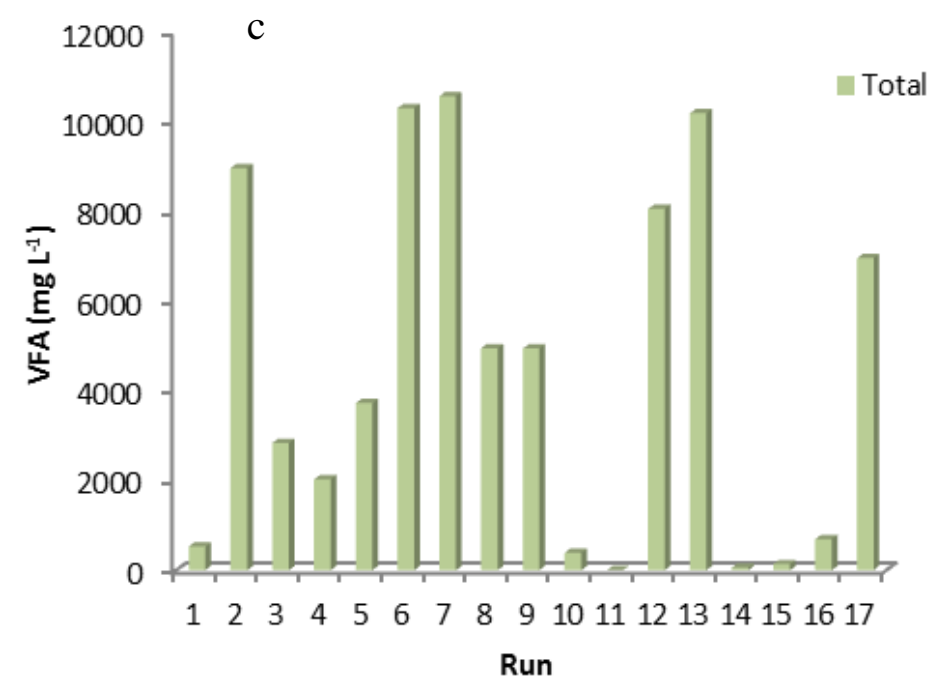

Figure S2. (a) VFA concentration at the beginning of the ammonia stripping experiment, (b) VFA concentration at the end of the ammonia stripping experiment, (c) VFA increase in the ammonia stripping experiments. 


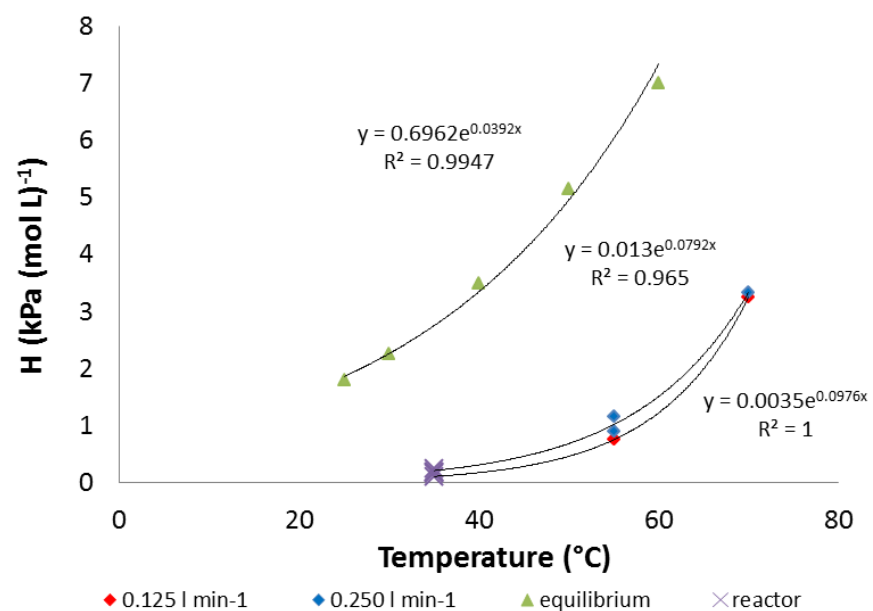

b

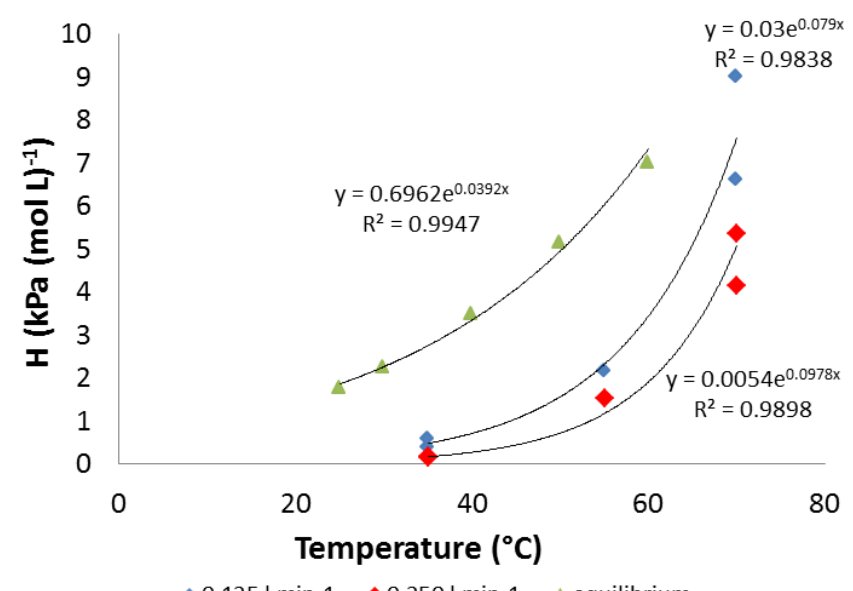

$\diamond 0.125$ I min-1 $\diamond 0.250$ I min-1 $\triangle$ equilibrium

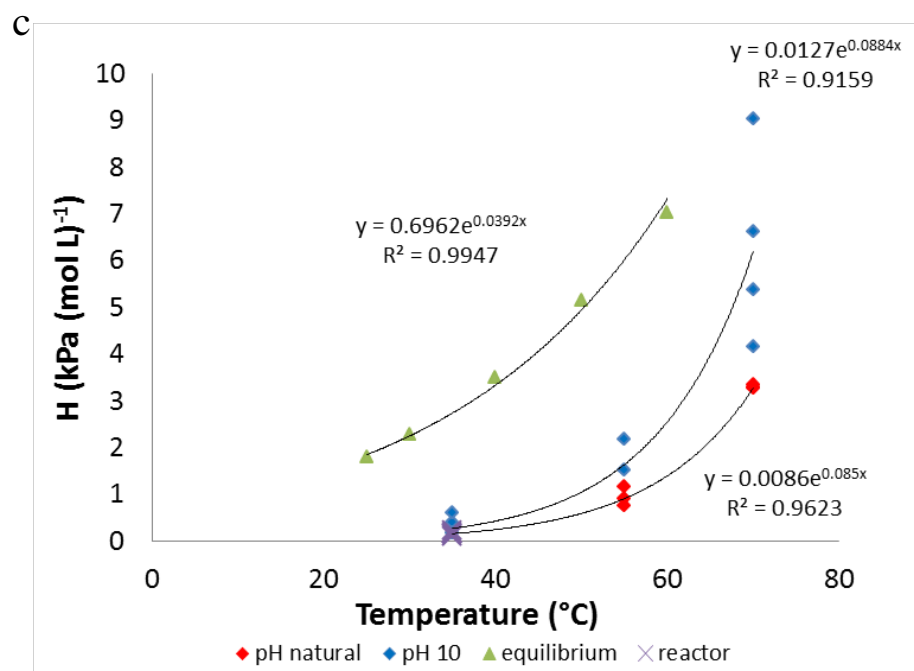

Figure S3. H values vs. temperature: (a) unadjusted $\mathrm{pH}$, flow comparison; (b) $\mathrm{pH}$ 10, flow comparison; (c) effect of temperature on $\mathrm{H}$ values. 